\title{
Stochastic convergence in per capita energy consumption and its catch-up rate: Evidence from 26 African countries
}

\author{
Lei Pan* \& Svetlana Maslyuk-Escobedo ${ }^{\dagger}$
}

\begin{abstract}
Using annual data from 1971 to 2014, we examine stochastic conditional convergence in per capita energy consumption and its catch-up rate for 26 low income, lower middle income and upper middle income African countries. To do so, we use a battery of conventional panel unit root tests, panel tests that allow for cross-sectional dependence and structural breaks as well as the recently developed univariate RALS-LM unit root test with structural breaks. Although for most countries we find evidence in support of stochastic conditional convergence, we find divergence for four countries including DR Congo, Senegal, Egypt and Botswana. The per capita energy consumption in Africa is growing faster than that of other countries, driven by improved infrastructure and inward investment from China. Over time, as regional energy consumption disparity narrows, we find African countries will catch up to China. This catching up effect will also affect China's overall energy demand in the future.
\end{abstract}

Keywords: energy consumption, catch-up rate, stochastic convergence, unit roots, cross-sectional dependence, structural breaks

JEL Classification: C12, O40, O43

\footnotetext{
* Corresponding author. Department of Economics Monash University 900 Dandenong Road, Caulfield East, Vic, 3145, Australia Email: lei.pan@ monash.edu

$\dagger$ School of Education and Arts Australian Catholic University 34 Brunswick St, Fitzroy, Vic, 3065, Australia Email: Svetlana.Maslyuk@acu.edu.au

The authors are grateful to Jinyue Yan and Mita Bhattacharya for their helpful comments and suggestions on the earlier versions of this paper. Lei would like to thank Prof. Vinod Mishra for sharing the codes of Pesaran (2004) cross-sectional dependence test and Pesaran (2007) CIPS unit root tests used in this study. All errors are our own.
} 


\section{Introduction}

Over the past 60 years, the African continent enjoyed poor income growth together with high and persistent population growth (Khan, 2014, p. 354). Lack of economic performance can be attributed to the colonial past, poor governance and corruption, insufficient investment in human capital (in particular, education and health), civil wars and regional conflicts. Many African economies recognised the need for a change and, due to prudential macroeconomic policies and favourable external factors between 2000 and the Global Financial Crisis (hereafter GFC), African countries were growing on average at $5 \%$ or more per year (African Development Bank (ADR), 2009). Since many African economies rely heavily on agriculture, limited manufacturing and extractive industries (Anoruo, 2014), they would require industrialisation which is impossible without an increase in energy consumption. Do energy consumption per capita levels among African nations converge towards a common level? Do energy consumption levels in low income and middle income African countries catch-up rate with those in China, an economy that grew from an agrarian state with limited manufacturing in the 1960s to a rapidly growing middle income economy? What are the important events (i.e. structural breaks) that affected the energy consumption path of African economies? This paper strives to answer these questions for 26 countries from the African continent (mainly North Africa and South Africa) from 1971 to 2014 using advanced recent panel and univariate tests for stochastic conditional convergence.

There are several types of convergence in the literature including absolute, club and conditional convergence ${ }^{1}$. In this paper, we focus on stochastic convergence, which is consistent with the conditional convergence hypothesis (Strazicich et al., 2004). Stochastic conditional convergence allows understanding the impact of shocks on the trajectory of energy consumption. More technically, if a country's per capita energy consumption relative to the group average is stationary, this is interpreted as the sign of convergence towards the group average (Fallahi, 2017), which implies that the impact of various shocks to energy consumption would be temporary in nature. Otherwise, the impact of shocks to energy consumption would have permanent effects. In addition to stochastic convergence, we analyse catch-up rate or the rate with which African nations can be potentially converging the level of a rapidly developing country (China). This allows for an understanding of how a nation's demand for energy will change over time as it moves from low income status to relatively higher income.

Studying stochastic conditional convergence in energy consumption is important for several reasons. First, because per capita energy consumption in addition to GDP per capita is one of the most commonly used measures of welfare (see for example Mohammadi and Ram, 2012; Meng et al., 2013), studying stochastic conditional convergence will allow an understanding of the impact of shocks to energy consumption. Since the current structure of African economies makes them very vulnerable to external and internal shocks, this has important implications from economic and environmental policy standpoints for each country in the sample. Second, in addition to being a vital input in the production of goods and services, energy consumption is the major contributor to human development. Currently, many African

\footnotetext{
${ }^{1}$ Galor (1996) defined 3 types of hypotheses on convergence. They are the absolute convergence hypothesis, where in our case per capita energy consumption or its catch-up rate of countries (or regions) converge to one another in the long-run, regardless of their initial conditions; the club convergence hypothesis, where per capita energy consumption or the catch-up rate are the same in their structural characteristics and in the long-run converge to one another, given their similar initial conditions; the conditional convergence hypothesis, where per capita energy consumption or its catch-up rate are the same in their structural characteristics and in the longrun converge to one another, regardless of their initial conditions.
} 
countries, especially in Sub-Saharan Africa, experience energy poverty that serves as an additional obstacle to economic development. Third, when formulating realistic targets for regional growth and greenhouse gas emissions, both domestic and global policy makers need to understand the path of convergence between less and more developed countries. Given the energy availability constraints (e.g. predominant use of non-renewable fossil fuels such as coal and petroleum (Anoruo, 2014) and limited involvement of renewables into the energy mix in Africa), poor access to essential energy services and infrastructure, uncertain geopolitical situations, convergence in energy consumption (and potentially economic growth) and catching up with other developing nations, such as China and potentially developed nations, could be even more difficult for African countries.

Studying convergence is not new and was investigated mostly for developed countries and some emerging nations (see Table 1 below). Recent trends in the literature include analysing large panels of data containing both developing and developed countries (Fallahi, 2017) as well as analysis of states within the same country (Mohammadi and Ram, 2017; Payne et al., 2017, Herreiras et al. 2017) or specific sectors of individual countries (Lean et al., 2016; Mishra and Smyth, 2017). The consensus among such studies is convergence in energy consumption per capita (see for example Meng et al., 2013; Payne et al., 2017). However, convergence levels of the developed and developing countries are not directly comparable and depend on the choice of the reference time frame with different initial conditions, prior history as well as the previous economic successes (Sy, 2016, p. 4-5).

The fact that literature has largely ignored the issue of energy consumption for African nations represents a significant gap because Africa represents an important case from the economic development perspective. Despite the efforts of regional integration, there is significant variation in per capita energy consumption among countries, access to essential energy infrastructure as well as the cost of energy. According to Oyuke et al. (2016), two major problems that affect these nations are the rolling blackouts (North Africa) and complete lack of essential electricity infrastructure (Sub-Saharan Africa). At the same time, the African continent has vast energy endowments (both renewable and non-renewable energy) which are not evenly distributed among countries (International Energy Agency (IEA), 2014). Together with the lack of essential infrastructure to generate and consume energy this creates significant energy poverty for some countries, especially the ones in SubSaharan Africa. For example, in Sub-Saharan Africa, as a whole, of the 915 million people only 290 million (or 25.13\%) have access to electricity (IEA, 2014, p. 13). Because $80 \%$ of those 600 million people without access to electricity live in rural areas, which are either financially or logistically problematic for the grid expansion, there is a stunning difference between rural and urban electrification rates (14.3\% vs 59\%, respectively). This is different from North Africa where more than $90 \%$ of the population has access to electricity (Oyuke et al., 2016) but which suffers from blackouts and irregularities in supply (Oyuke et al., 2016). In addition to these issues of poor reliability and access to energy, the World Bank (2017) lists the high cost of energy as an additional key factor that affects Africa's energy sector today. For instance, in Sub-Saharan Africa the average electricity tariff is US\$0.14 while in other developing countries energy tariffs range from US $\$ 0.04$ to US $\$ 0.08{ }^{2}$.

\footnotetext{
2 refer to the website of the World Bank:

http://web.worldbank.org/WBSITE/EXTERNAL/COUNTRIES/AFRICAEXT/0,,contentMDK:21935594 page PK:146736 piPK:146830 theSitePK:258644,00.html
} 
This paper makes the following contribution to the literature. First, this paper focuses on Sub-Saharan and North Africa; the former is a region with extreme energy poverty and the latter is a region with large scale access to unreliable electricity resources. Focusing solely on Africa allows us to obtain more robust results as compared to previous panel studies which investigated both developed and developing countries together. Understanding African energy consumption dynamics is crucial as energy consumption is closely linked with environment, poverty and economic growth on the continent. Since there is a close relationship between energy consumption and economic growth (see for example: Yuan et al, 2008; Ozturk et al, 2010; Tsani, 2017; Belke et al, 2011), we split the sample into low income, lower middle income and upper middle income levels based on the income levels classification proposed by the World Bank ${ }^{3}$.

Second, due to the convergence findings in the majority of the existing studies for high income and other developing non-African nations, the implications for potential divergence in energy consumption largely have been ignored in the literature. In fact, several studies have found divergence in income levels in Africa (Djennas and Ferouani, 2014; Ranjbar, et al., 2014) which could be potentially linked to divergence in energy consumption. Given substantial heterogeneities between countries in the sample, including significant spread in access to energy resources, disparities in energy infrastructure, historical conditions (some of the nations have colonial background), government issues including wide-spread corruption, civil wars, and terms of trade shocks, we should expect to find divergence in energy consumption for some African countries. Divergence in energy consumption indicates that an adverse supply shock to these economies will have a permanent macroeconomic effect, such as lower productivity, lower output and high unemployment that may further exacerbate poverty. The present study fills this gap by providing policy implications for divergence in energy consumption which are ignored in the previous studies.

Third, we investigate stochastic convergence among per capita energy consumption by adopting the Pesaran (2007) cross-sectionally augmented IPS (CIPS) panel unit root tests as well as the Carrion-i-Silvestre et al. (2005) panel KPSS unit root tests that allow multiple (up to five) structural breaks which are endogenously determined in the data. This enables us to reject a false unit root null hypothesis unambiguously. The advantage of CIPS is that it controls for cross-sectional dependence of the errors. It is particularly appropriate to use African data as it is reasonable to expect that economic, political and cultural interrelationships can lead to cross-country correlations that will affect our results. Carrion-iSilvestre et al.'s (2005) panel KPSS test has the following advantages: first, it includes individual fixed effects and/or an individual specific time-trend, and second, the test allows for multiple structural breaks that may potentially appear at different unknown dates in addition to varying numbers of breaks for each individual panel member. It should also be noted that convergence results given by the conventional panel unit root tests without structural breaks might not be reliable. To check the robustness of our results we use the recently developed Residual Augmented Least Squares-Lagrange multiplier (RALS-LM) unit root test by Meng et al. (2014). As compared to other tests, RALS-LM tests allow for trend

\footnotetext{
${ }^{3}$ World Bank categorizes all countries into four groups based on their income levels. For the current 2018 fiscal year, low-income economies are those with a GNI per capita, calculated using the World Bank Atlas method, of $\$ 1,005$ or less in 2016; lower middle-income economies are those countries with a GNI per capita between $\$ 1,006$ and $\$ 3,955$; upper middle-income economies are those with a GNI per capita between $\$ 3,956$ and $\$ 12,235$; high-income economies are those with a GNI per capita of $\$ 12,236$ or more.
} 
breaks under the null hypothesis and utilize information on non-normal error terms making them superior to non-linear tests which tend to perform poorly when faced with non-normal errors (Meng et al., 2014).

Fourth, in addition to investigating stochastic convergence, we estimate the catch-up rate between per capita energy consumption in African countries with per capita energy consumption in China. China was chosen for this analysis for two reasons: First, it represents a development path from an agrarian economy with limited manufacturing and significant extractive resources (the situation that many of the poorest African countries are in currently) to a post-industrial society in a relatively short period of time. Second, over the past decades, China has become the leading financier of global infrastructure, particularly in the African continent. A report from the Brookings Institution ${ }^{4}$ showed that between 2009 and 2012, China was the single largest infrastructure financier in 11 African nations. China doubled its effort in Africa in December 2015, pledging an additional $\$ 60$ billion in aid. Furthermore, the recently developed Asian Infrastructure Investment Bank (AIIB) is an extraordinary initiative to finance infrastructure projects in the developing world.

The remainder of the paper is organized as follows. Section 2 presents a brief review of related studies. In Section 3, we discuss the data. Section 4 is devoted to the framework used for catch-up rate. Section 5 presents the empirical methodology used in this study. Section 6 reports findings, section 7 interprets the break dates. Section 8 provides discussion of results and policy implications, and Section 9 concludes the paper.

\section{Literature Review}

The work on examining stationarity and integration properties of energy variables is pioneered by Narayan and Smyth (2007). Since then, the literature has flourished with testing a unit root in energy consumption as the preliminary analysis to identifying long-run relationship and causality patterns between energy, economic growth and other variables of interest.

Based on the methodologies used, the existing studies on conditional stochastic convergence in per capita energy consumption can be classified into four broad sets. The first one consists of studies applying univariate unit root tests such as conventional Augmented Dickey Fuller (ADF) and Phillips Perron (PP) unit root tests. For instance, applying the ADF unit root test to annual energy consumption data from 1979 to 2010 for 182 countries, Narayan and Smyth (2007) found energy consumption was convergent for 31 percent of their sample. Nonetheless, the classical univariate unit root tests have several limitations which make them not sufficiently reliable. First, the ADF test is likely to provide a biased result in the presence of structural breaks. Second, the ADF and PP test series are linear, hence, they have low power to reject the unit root null if the data process is non-linear. For these reasons, the literature on stochastic conditional convergence has moved to unit root tests with structural breaks (second set), panel unit root tests (third set) and non-linear unit root tests (fourth set).

\footnotetext{
${ }^{4}$ Refer: Gutman, J., Sy, A. \& Chattopadhyay, S. (2015). Financial African Infrastructure: Can the world deliver? available at: https://www.brookings.edu/wp-content/uploads/2016/07/AGIFinancingAfricanInfrastructure_FinalWebv2.pdf
} 
The second stream of conditional convergence literature (such as Lee and Strazicich, 2003; Narayan and Popp, 2010) employed univariate unit root tests with structural breaks to address non-rejection of unit root null hypothesis due to failure to consider structural breaks in the data. Most studies found energy consumption is stationary around a broken trend (see for example: Apergis and Payne, 2010; Narayan et al., 2010). Moreover, Mishra and Smyth (2014) when testing convergence in energy consumption per capita in the ASEAN-5 between 1971 and 2011 found mixed evidence of convergence with univariate tests with breaks. While earlier studies utilised country-level data at low frequency, more recent studies concentrate on examining the convergence issue at the sector or organization level (Lean et al., 2016; Mishra and Smyth, 2017). For example, using annual energy consumption per capita data at the sector level in Australia over the period 1973-74 to 2013-14, Mishra and Smyth (2017) found evidence of convergence in energy consumption in six of seven industry sectors in Australia.

The third set of studies applied non-linear stationarity tests to avoid the drawbacks of the ADF and PP tests discussed earlier. As shown by Hasanov and Telatar (2011) and Alper and Hakan (2011), energy variables can be potentially non-linear in mean. For example, Öztürk and Aslan (2015) studied stationary properties of per capita electricity consumption by employing a non-linear unit root Lagrange Multiplier and Kruse's (2011) test for 23 OECD countries from 1960 to 2005 . They found non-linear behaviour in electricity consumption for $70 \%$ of the OECD countries. Moreover, for electricity consumption was found to be a nonstationary process for 12 countries.

While earlier studies focused on individual countries, studies utilising panel data (either large panels of countries or state-level) with or without structural breaks have emerged to overcome shortcomings of conventional univariate unit root tests. Studies that employed panel unit root tests without breaks provide mixed stationarity results (see for example: Agnolucci and Venn, 2011; Shahbaz et al., 2016), while studies that applied panel unit root tests with breaks are unanimous in supporting stochastic convergence in energy consumption, which implies that the impact of shocks on energy consumption is likely to be temporary (see for example: Mishra and Smyth, 2014; Acaravci and Erdogan, 2016). A summary of recent literature is presented in Table 1 to conserve space. In relation to Africa, despite Anorou and DiPietro (2014) and Fallahi (2017), there was very limited work on per capita energy consumption convergence among countries from the African continent, and to the best of our knowledge no literature had previously examined the catch-up rate between energy consumption of African countries and China. Using conventional panel unit root tests for 22 African countries, Anorou and DiPietro (2014) found that per capita energy consumption series have converged as a group, meaning that shocks to energy consumption were temporary and mean reverting. However, once they introduced Sequential Panel Selection Methods (SPSMS) methodology, for some countries (Tunisia, Cote d'Ivoire, Sudan, Gabon, Zimbabwe, Morocco and Togo) energy consumption paths appeared to be diverging from the group average. The SPSMS was criticized by Costantini and Lupi (2014) using Monte Carlo simulations and based on generating the individual test statistics and the $p$-values to be combined into panel stationarity tests, they examined the reliability of SPSMS under both the unit root null and the selected local alternatives. Their analysis showed that SPSMS does not perform better than the traditional time series unit root tests. Other studies such as Fallahi (2017) consider African energy consumption convergence but only as a part of the larger 
panel. Using interval estimation methods, Falahi (2017) argued that regional-specific characteristics are important when analysing stochastic convergence and reported strong evidence in favour of stochastic convergence for Africa.

\section{[Insert Table 1 Here]}

To sum up, the most relevant studies examine the existence of convergence of various kinds. However, up to now, there has been almost no research on the convergence in energy consumption in Africa. Moreover, the implications for divergence in energy consumption largely have been ignored in the literature. In addition, only a few researchers have investigated the breakpoints of convergence (or changes in convergence trends over time) and cross-sectional dependence in the data. Hence, estimation results that did not consider these issues may be unreliable and not robust. The present study attempts to fill the research gaps addressed above.

\section{Data}

Data on per capita energy consumption (in $\mathrm{kg}$ of oil per capita) are from the World Development Indicators (WDI) ${ }^{5}$ Database of the World Bank. Our sample consists of 26 African countries from North Africa and Sub-Saharan Africa, which were further split into three panels based on the income levels (low income, lower middle income and upper middle income) of the World Bank's country income classification. Table 2 presents countries in the sample split by the income level.

The time period of the analysis is from 1971 to 2014 with the exception of Botswana (1981 to 2014) and Zambia and Zimbabwe (1971 to 2013). This time period corresponds to the postcolonial development of the African nations. Moreover, to examine the catch-up rate for the African economies with a more advanced developing country, we also collect Chinese energy consumption per capita data for the sample period. Figure 1 plots the trends in energy consumption per capita for each income panel. The figure suggests that except for Panel A (low income) energy consumption per capita for other economies converges to the average value of its panel.

\section{[Insert Table $2 \&$ Figure 1 Here]}

Tables 3 and 4 present descriptive statistics of per capita energy consumption for different economies in Africa and China, and the catch-up rate estimated with Eq. (2) below and catchup growth rate (defined as the first difference of catch-up rate), respectively. Descriptive statistics show that there is a great disparity between energy consumption levels between poorer and relatively richer African nations.

\section{[Insert Table 3 \& Table 4 Here]}

The empirical analysis is based on relative per capita energy consumption for each country $i$, which is a transformed series of energy consumption per capita using the equation below:

\footnotetext{
${ }^{5}$ The World Bank defines energy use as the use of primary energy before transformation to other end-use fuels, which is equal to indigenous production plus imports and stock changes, minus exports and fuels supplied to sea vessels and aircraft engaged in international transport.
} 
Relative energy consumption $n_{i t}=\ln \left(\frac{G_{i, t}}{A G_{t}}\right)$

where $A G_{t}$ stands for the average energy consumption per capita for each specific economy in the sample. The main purpose of transforming the data is to ensure cross-sectional independence by removing common shocks that can influence all countries in the sample. Specifically, any negative shocks to the energy consumption across all countries will reduce the average energy consumption amount by the same proportion, hence the relative energy consumption remains constant and the structural breaks identified in the transformed series will be country specific.

\section{Catch-up rate framework}

The theoretical foundation of the catch-up hypothesis can be traced to the neoclassical Solow-Swan model. Following Solow (1956) and Barro and Sala-i-Martin (1991), real per capita incomes are inversely related to the initial income levels corresponding to the early stages of development. This implies poorer countries tend to grow faster than the richer countries and can potentially over time catch-up with the income levels of richer nations. Since energy use is an important factor in growing income, the hypothesis of the catch-up rate in energy consumption (consistent with the neoclassical growth models) would imply that African nations that have low per capita energy consumption levels should grow their energy consumption faster (i.e. catch-up) than China, which is not yet a developed country but until recently has been growing rapidly. Since the market reforms started in 1978, China has transformed from a centrally planned to a market-based economy. Its annual GDP growth has averaged nearly 10 percent, which is the fastest sustained economic expansion by a major economy in history, and has helped more than 800 million people out of poverty ${ }^{6}$. China had undergone rapid industrialization also. China is now the second largest economy in the world and is increasingly playing a significant role in global economic development. Post GFC China has been the largest contributor to world economic growth. Yet, China remains a developing country and market reforms are incomplete. The rapid economic growth also brought many challenges to China which include: rapid urbanization, environmental sustainability, high income inequality, and so on. Hence, China needs significant policy adjustments to achieve sustainable economic growth which would require changes in its energy mix towards renewable energy. This would suggest that shifting from a middle income to a high income country can be far more difficult than transitioning from a low income to a middle income country.

In this study, we use the Barro and Sala-i-Martin (2004) approximation as a framework for calculating the energy consumption catch-up rate. The approximation is as follows:

$D\left(\log G_{t}-\log G_{t}^{*}\right)=\lambda\left(\log G_{t}-\log G_{t}^{*}\right)$

where $G_{t}$ is per capita energy consumption, $G_{t}^{*}$ denotes the steady-state value of $G_{t}, D\left(\log G_{t}\right.$ - $\log G_{t}^{*}$ ) refers to the growth rate of $\log G_{t}-\log G_{t}^{*}$ and $\lambda$ is a negative parameter. If $\log G_{t}$ $\log G_{t}^{*}<0$ current per capita energy consumption is less than its steady-state value, resulting in $D\left(\log G_{t}-\log G_{t}^{*}\right)>0$ since $\lambda<0$.

\footnotetext{
${ }^{6}$ Refer to the World Bank website: http://www.worldbank.org/en/country/china/overview
} 
In this paper, $G_{t}^{*}$ is proxied by the per capita energy consumption in China. We define $X_{i, t}=$ $\log \left(G_{i, t} / G_{\text {china, },}\right)$ where $G_{i, t}$ is the per capita energy consumption of country $i$ in year $t$ and $G_{\text {china,t }}$ represents the per capita energy consumption of China. Eq. (2) shows that $X_{i, t}$ should be stationary, and perhaps with a broken trend.

Figures 2 and 3 show the evolution of the catch-up rate and the catch-up growth rate respectively. One can see that over time the difference between the energy consumption per capita in African countries has been reducing as compared to energy consumption in China. That is, over the time, there is a tendency for African nations to catch-up with the energy consumption levels of China. Over the past few years, China has rapidly become the number one country in global energy demand. The US EIA reported that China surpassed the US at the end of 2013 and became the world's largest net importer of petroleum and other liquids. In 2014, China's oil consumption growth accounted for around $43 \%$ of the world's oil consumption ${ }^{7}$. Figure 3 shows that for low and upper middle income catch-up growth rates were very volatile over time. For some low income economies, the growth rates became bigger towards the end of the sample period. For the upper middle income countries, catch-up growth rates were relatively stable over time and less volatile as compared to the low and lower middle income nations. However, the exception was Libya where growth rates have tanked post 2010, which is the reflection of the on-going war.

[Insert Figure $2 \&$ Figure 3 Here]

\section{Econometric Methodology}

In this paper, we use a wide range of recent conventional panel unit root tests as well as the panel unit root tests with structural breaks to investigate the stochastic convergence of per capita energy consumption and its catch-up rate. Panel unit root tests are considered to be more powerful than time series unit root tests because they combine information from both time series and cross-sectional dimensions. In this paper, we utilise two conventional panel tests without structural breaks (Levin et al. (2002) (LLC hereafter), Hadri (2000) panel LM tests root test) that will serve as a benchmark for panel analysis. Results of these tests are presented in the Appendix. If the cross-sectional dependence is found in the data, then the conventional panel unit root tests without structural breaks will have large size distortions (see Maddala and Wu, 1999; Banerjee et al., 2005). To examine whether the transformation has removed the cross-sectional dependence in our panel, following Pesaran (2004) we estimate individual $\operatorname{ADF}(p)$ regressions for lag length $(p)=1,2,3$ and 4 and calculate pairwise cross-section correlation coefficients of the residuals from these regressions (namely $\hat{\rho}_{i j}$ ). If the cross-sectional dependence is found to be present in the data, we employ the Pesaran (2007) CIPS panel unit test. Another potential problem of the conventional panel unit root tests is that these tests do not consider potential structural breaks in the data, which can lead to erroneous results. According to Bacon and Mattar (2005), African countries are particularly sensitive to shocks such as the oil crisis due to the low energy intensity in Africa, inefficient energy supply mix (despite significant potential for renewable energy resources including solar, wind and hydro) and dependence on imported oil as the primary energy source for many countries. To avoid such a result in this paper, we use the Carrion-i-Silvestre

\footnotetext{
${ }^{7}$ Refer the EIA website: https://www.eia.gov/beta/international/analysis.cfm?iso=CHN
} 
et al. (2005) panel KPSS unit root test with multiple structural breaks for the whole panel as well as individual countries.

Furthermore, we adopt the recently developed univariate RALS-LM unit root test by Meng et al. (2014) as a robustness check. The test has improved power with non-normal errors and is robust to some forms of non-linearity (Meng et al., 2013). By applying the RALS-LM unit root test, we are able to remove the dependency of the test statistic on nuisance parameters that many endogenous break unit root tests have.

\subsection{Carrion-i-Silvestre et al. (2005) panel KPSS unit root test with multiple breaks}

This test has a null hypothesis of stationarity which addresses the criticism by Bai and $\mathrm{Ng}$ (2004) that it is more natural to take stationarity than non-stationarity as the null hypothesis for most economic applications. The Carrion-i-Silvestre et al. (2005) panel KPSS test model specification is as follows:

$y_{i t}=\alpha_{i}+\sum_{k=1}^{m_{i}} \theta_{i, k} D U_{i, k, t}+\beta_{i} t+\sum_{k=1}^{m_{i}} \gamma_{i, k} D T_{i, k, t}^{*}+\varepsilon_{i, t}$

where $y_{i t}$ is the relative energy consumption per capita in country $i$ at time $t ; t=1, \ldots, \mathrm{T}$ which stands for time period and $i=1, . ., \mathrm{N}$ represents number of panel members and $\varepsilon_{i, t}$ is the error term. $D U_{i, k, t}$ and $D T_{i, k, t}^{*}$ are dummy variables defined as $D U_{i, k, t}=1$ for $t>T_{b, k}^{i}$ otherwise 0 , and $D T_{i, k, t}^{*}=t-T_{b, k}^{i}$ for $t>T_{b, k}^{i}$ otherwise 0 . The term $T_{b, k}^{i}$ stands for the $\mathrm{k}^{\text {th }}$ date of the break for the $\mathrm{i}^{\text {th }}$ individual where $k=\left\{1, \ldots, m_{i}\right\}, m_{i} \geq 1$.

Eq. (3) is the panel counterpart with structural breaks for the univariate framework. It allows for structural shifts in the trend of the individual series in the panel and permits each country in the panel to have a different number of breaks occurring at different dates in time.

The test is a generalization for the case of multiple changes in the level and slope of Hadri's (2000) panel unit root test, which is the average of the univariate Kwiatkowski et al. (1992) stationarity test. The test statistic is as follows:

$\operatorname{LM}(\lambda)=N^{-1} \sum_{i=1}^{N}\left(\widehat{\varpi}_{i}^{-2} T^{-2} \sum_{i=1}^{T} S_{i, t}^{2}\right)$

where $S_{i, t}=\sum_{j=1}^{t} \hat{\varepsilon}_{i, t}$ denotes the partial sum obtained from the OLS residuals of Eq. (4), and $\widehat{\varpi}_{i}^{2}$ is a consistent estimation for the long run variance of residual $\varepsilon_{i, t}$ which allows the heteroskedastic disturbance among cross-sectional units. The test statistic for the null hypothesis of a stationary panel with multiple shifts under the cross-sectional independence assumption and the distribution of the test statistic via bootstrap is as follows:

$Z(\lambda)=\frac{\sqrt{N(\operatorname{LM}(\lambda)-\bar{\xi})}}{\bar{\zeta}} \rightarrow N(0,1)$

where $\bar{\xi}$ and $\bar{\zeta}$ are the averages of the individual means and variances of $\operatorname{LM}(\lambda)$, respectively.

According to Carrion-i-Silvestre (2005), estimation for the number of structural breaks and their locations are based on the procedure developed by Bai and Perron (1998) that calculates total minimization of the sum of the squared residuals (SSR). The procedure and selection of 
the break dates are based on minimizing the sequence of individual $\operatorname{SSR}\left(T_{b, 1}^{i}, \ldots, T_{b, m i}^{i}\right)$ and is expressed as:

$\left(\widehat{T}_{b, 1}^{i}, \ldots, \widehat{T}_{b, m i}^{i}\right)=\arg \min \operatorname{SRR}\left(T_{b, 1}^{i}, \ldots, T_{b, m i}^{i}\right)$

In the present study, following Bai and Perron (2005), the number of breaks for each individual country is estimated using the modified Schwartz Information Criterion. Following the suggestions of Carrion-i-Silvestre (2005), we allowed five as the maximum number of breaks. Furthermore, we compute the finite sample critical values by Monte Carlo simulations with 2000 replications. Namely, we use bootstrap techniques to approximate the empirical distribution of the panel data statistic to avoid cross-sectional independence assumption.

\subsection{RALS-LM unit root tests with structural breaks}

Before implementing the RALS-LM tests, we first identify whether breaks exist in the data, and if so, they should entail one or two breaks by applying the procedure developed by Perron and Yabu (2009) and Kejriwal and Perron (2010). This makes our findings more reliable over the existing literature on convergence that employed stationarity test methodology that accounts for endogenous breaks in the trend function under the trend stationary alternative. If the series under consideration contains no breaks, this testing approach has lower power due to accounting for extraneous break dummies, hence leading researchers to suffer the model misspecification issue. The Perron and Yabu (2009) method is implemented first to test the null hypothesis of no breaks against the alternative hypothesis of one break. For those countries where Perron and Yabu (2009) identified there is one break, the Kejriwal and Perron (2010) procedure is used to test the null of one break against the alternative of two breaks. This method helps us to verify the number of structural breaks for each country.

Assume the following data generating process:

$y_{t}=\psi+\xi t+x_{t}, \quad x_{t}=\beta x_{t-1}+e_{t}$

The null hypothesis is $\beta=1$ against the alternative of $\beta<1$. The parameters $\psi$ and $\xi$ stand for the deterministic components of intercept and trend, respectively. The model can be written in a general form as follows:

$$
y_{t}=z_{t}^{\prime} \delta+x_{t}, \quad x_{t}=\beta x_{t-1}+e_{t}
$$

where $z_{t}^{\prime}$ is the deterministic terms including potential structural changes. For example, with an intercept, trend and $R$ breaks, $z_{t}^{\prime}$ can be represented as $\left[1, t, D_{1 t}, \ldots, D_{R t}\right]$, where $D_{j t}=1$ for $t \geq T_{B j}+1, j=1, \ldots, R$ and zero otherwise. The LM test statistic can be obtained by conducting the following regression:

$\Delta y_{t}=\delta^{\prime} \Delta z_{t}+\phi \tilde{y}_{t-1}+\sum_{j=1}^{p} g_{i} \Delta \tilde{y}_{t-1}+e_{t}$

where $\tilde{y}_{t}=y_{t}-\tilde{\psi}-z_{t} \tilde{\delta}, t=2, \ldots, T ; \tilde{\delta}$ denotes the coefficient vectors of $\Delta z_{t}, \tilde{\psi}$ is the restricted maximum likelihood estimate of $\psi$, which equals $y_{1}-z_{1} \tilde{\delta} ; y_{1}$ and $z_{1}$ refer to the first observation of $y_{t}$ and $z_{t}$, respectively. The term $\Delta \tilde{y}_{t-j}$ represents the lagged differences 
which are included in the regression to control for auto-correlated errors. The LM test statistic (denoted as $\tilde{\tau}_{L M}$ ) is the t-statistic testing the null hypothesis of $\phi=0$ in Eq. (9).

Meng et al. (2014) improved this procedure by utilizing information in the higher moments of non-normal errors to infer the nature and functional form of non-linearity. This can be achieved by defining $\xi_{t}=\left(\Delta \tilde{y}_{t-1}, \Delta \tilde{y}_{t-2}, \ldots, \Delta \tilde{y}_{t-p}\right)^{\prime}, f_{t}=\left(\tilde{y}_{t-1}, \xi_{t}^{\prime}\right)^{\prime}$ and $F_{t}=\left(\Delta z_{t}{ }^{\prime}, f_{t}{ }^{\prime}\right)^{\prime}$ and also needs to satisfy the following two moment conditions:

$E\left[e_{t} \otimes F_{t}\right]=0$

$\mathrm{E}\left[\left(h\left(e_{t}\right)-K\right) \otimes F_{t}\right]=0$

where $e_{t}$ is the residuals from equation (9), $K=E\left(e_{t}\right)$ and $h\left(e_{t}\right)$ represents a non-linear function of $e_{t}$.

Meng et al. (2014) defined the items below by following a similar approach proposed by Im and Schmidt (2008): $h\left(\hat{e}_{t}^{2}, \hat{e}_{t}^{3}\right)^{\prime}, \widehat{K}=\frac{1}{T} \sum_{t=1}^{T} h\left(\hat{e}_{t}\right), \widehat{D}_{2}=\frac{1}{T} \sum_{t=1}^{T} h^{\prime}\left(\hat{e}_{t}\right)$ and $m_{j}=T^{-1} \sum_{t=1}^{T} \hat{e}_{t}^{j}$ and Eq. (9) with the term below:

$\widehat{w}_{t}=\left[\hat{e}_{t}^{2}-m_{2}, \hat{e}_{t}^{3}-m_{3}-3 m_{2} \hat{e}_{t}\right]^{\prime}$

The final specification of the RALS-LM unit root test is as follows:

$\Delta y_{t}=\delta^{\prime} \Delta z_{t}+\phi \tilde{y}_{t-1}+\sum_{j=1}^{p} g_{j} \Delta \tilde{y}_{t-j}+\widehat{w}_{t}^{\prime} \gamma+u_{t}$

The RALS-LM test statistic is generated via least squares estimations and the t-statistic used to test the null of $\phi=0$ is denoted as $\tau_{R A L S-L M}^{*}$. The asymptotic distribution of $\tau_{R A L S-L M}^{*}$ and the asymptotic critical values for the test for different combinations of $T$ and $\rho$ are provided in Meng et al. (2014). Notice that the RALS-LM test statistic does not depend on the parameters of break points, thus the same critical values can be applied regardless of the number of structural breaks identified in the data series.

The locations of the structural breaks, the significance of break dummies and the optimal number of lags for the RALS-LM tests are all determined using a $\max F$ test. In this study, we set the trimming region to $10 \%$ by following Meng et al. (2013), hence the grid search of breaks is restricted in the range between $0.10-0.90$ of our sample. Moreover, the structural breaks are restricted to be at least 0.1 of the sample apart, which is to ensure data points before and after breaks are enough for estimation. The optimal lag length is selected by employing a Hull's general to specific procedure, with the maximum number of lags allowed is eight.

\section{Results and Discussion of Findings}

Used as a benchmark (see Appendix for tabulated results), the results of the conventional panel unit root tests reveal that there is strong evidence of divergence in both per capita energy consumption and catch-up rate with China in African economies.

Table 5 presents the simple average of the pair-wise cross-section correlation coefficients across all pairs $(\overline{\hat{\rho}})$ together with the cross-section dependence $(C D)$ test statistic. The results for both untransformed and transformed series are reported under each panel. For the 
untransformed series, the Pesaran CD statistic is not significant at all four lags for both Panel $\mathrm{A}$ and $\mathrm{B}$, implying non-rejection of the null hypothesis of cross-sectional independence. After transforming the series, the null hypothesis is rejected at the $1 \%$ level for all three panels. Similarly, cross-sectional dependence is also found in the catch-up rate series. Since the transformed energy consumption series and the catch-up rate contain cross-sectional dependence, there is a need to apply CIPS unit root test methodology that takes this issue into account.

\section{[Insert Table 5 Here]}

Table 6 reports the CIPS test for the panel as a whole for African economies. Table 6 suggests that neither energy consumption per capita nor the catch-up rate contain a panel unit root at all four lags at the $1 \%$ level. The null hypothesis of panel non-stationarity is rejected at one lag for lower middle income economies only. Hence, this result implies that after considering cross-sectional dependence in the data, both per capita energy consumption and its catch-up rate converge towards their long-run levels.

\section{[Insert Table 6 Here]}

Table 7 presents the results of the panel KPSS test which allows for multiple structural breaks. Similar to Table 6, the null hypothesis of stationarity cannot be rejected at the 5\% level or better for both per capita energy consumption and its catch-up rate. The results confirm that after taking into account both cross-sectional dependence and structural breaks, the energy consumption per capita and the catch-up rate stochastically converge for all the panels grouped by the level of income. The different findings using the conventional panel unit root test and panel CIPS and KPSS test suggest that ignoring cross-sectional dependence and structural breaks can result in imprecise inference.

\section{[Insert Table 7 Here]}

Although we find evidence of convergence for all of the panels, as argued in Anorou and DiPietro (2014), it does not necessarily indicate the existence of convergence for each individual country to the group's average. Hence, we further employ both conventional time series unit root tests as well as tests with structural breaks to investigate the convergence issue in each country. Using the conventional tests (ADF, PP and KPSS), we find that the per capita energy consumption for five countries (Panel A: Togo; Panel B: Morocco, Sudan, Zambia; Panel C: Mauritius) are converging towards the mean value of their respective panels. Moreover, the catch-up rates of five countries (Panel D: Mozambique, Senegal, Tanzania; Panel E: Cote d'Ivoire, DR Congo) stochastically converge to the level of China during 1971-2014.

To avoid the issue of cross-sectional dependence, we further apply Pesaran (2007) CIPS time series stationarity test (see results of Pesaran (2007) CIPS test in Table 8). Results of the CIPS unit root test demonstrate a failure to reject the null of non-stationarity for most nations, which confirms Anorou and DiPietro's (2014) argument. In particular, the null hypothesis that per capita energy consumption is diverging can be rejected at the $5 \%$ level or better for only two countries at lag 1 and 2, and for none at lag 3 . In addition, the null hypothesis is rejected for three countries at lag 4 at the $10 \%$ level or better. For the catch-up rate, the null of unit root is rejected at the $10 \%$ level or better for seven countries at lag 1 , is rejected for only three countries at lags 2 and 3, and for none at lag 4 . The overall conclusion based on 
these test results is that the per capita energy consumption and its catch-up rate diverge for most African nations in the sample.

\section{[Insert Table 8 Here]}

Table 9 presents the results of individual countries for the Carrion-i-Silvestre et al. (2005) KPSS unit root test, while critical values are presented in the Appendix. The test is performed by allowing a maximum number of breaks up to five in the intercept and trend of each nation's series. Three to four structural breaks are found to be significant for most of the African countries. Table 9 reports the significant breaks only. After taking into account multiple structural breaks, the null hypothesis of stationarity is found to be rejected in 18 and 20 countries for the relative per capita energy consumption and its catch-up rate, respectively, at the $10 \%$ level or better.

\section{[Insert Table 9 Here]}

The results of the RALS-LM unit root tests can be conducted with zero, one or two structural breaks in the series. The Perron and Yabu (2009) and Kejriwal and Perron (2010) tests for identifying the number of breaks in relative energy consumption per capita and its catch-up rate for each of the 26 African countries are presented in Table 10. More than half of the African countries have two structural breaks in per capita energy consumption. Specifically, for six countries (Panel A: DR Congo, Zimbabwe; Panel B: Angola, Morocco, Zambia; Panel C: Botswana) there are no breaks, for six countries (Panel A: Mozambique, Togo; Panel B: Egypt, Tunisia; Panel C: Algeria, Libya) there is one break and for 14 countries (Panel A: Benin, Ethiopia, Senegal, Tanzania; Panel B: Cote d'Ivoire, Cameroon, DR Congo, Ghana, Kenya, Nigeria, Sudan; Panel C: Gabon, Mauritius, South Africa) there are two breaks. In terms of the catch-up rate, the vast majority of countries have one break in the series. In particular, there are no breaks for seven countries (Panel D: DR Congo, Mozambique, Tanzania; Panel E: Angola, Zambia; Panel F: Gabon, South Africa), there is one break for 16 countries (Panel D: Benin, Ethiopia, Senegal, Togo, Zimbabwe; Panel E: Cote d'Ivoire, Cameroon, DR Congo, Egypt, Kenya, Morocco, Nigeria, Sudan, Tunisia; Panel F: Botswana, Mauritius) and there are two breaks for three countries (Panel E: Ghana; Panel F: Algeria, Libya).

\section{[Insert Table 10 Here]}

The results for the RALS-LM unit root tests for relative energy consumption per capita and its catch-up rate in each country in the sample with the number of breaks identified using the Perron and Yabu (2009) and Kejriwal and Perron (2010) approaches, are provided in Table 11. The null hypothesis of a unit root in relative energy consumption per capita is rejected at the $10 \%$ level or better for six of the eight countries for Panel A, for eleven of the twelve countries for Panel B and for five of the six countries for Panel C. Similarly, the null of nonstationarity in catch-up rate is rejected at the $10 \%$ level or better for almost half of the African countries. Specifically, the catch-up rate converges for three out of the eight countries for Panel D, for six out of the twelve countries for Panel E and for three out of the six countries for Panel F.

Overall, we conclude that there is convergence in per capita energy consumption for the majority of countries in the sample, and the catch-up rates stochastically converge to the level of China for almost half of the African countries. The different findings in convergence from 
Table 8 and Table 9 highlight the fact that failure to verify the optimal number of breaks in the series can lead to biased results.

$$
\text { [Insert Table } 11 \text { Here] }
$$

\section{Discussion of estimated break dates}

Many of the African economies have liberalised trade policies since the 1970s but their involvement in global trade is limited to producing and exporting a few raw materials and primary goods including oil, copper, gold, diamonds, coffee, tobacco (Ranjbar, et al., 2014). This makes these economies prone to trade shocks (Ranjbar, et al., 2014) and vulnerable to external economic conditions, as our results show. In this section, we provide plausible reasons for the structural breaks identified by the RALS-LM unit root tests (Table A4 in the Appendix contains a brief discussion of the estimated break dates). These events can only be regarded as possible events associated with breaks but not as evidence of a statistical linkage with the proposed events or with the time periods of structural breaks. This is a limitation of our study which requires further investigation.

Only four countries experienced a structural break in the 1980s. These include Ghana (1982), Ethiopia (1983) Senegal (1983) and Congo (1985). With much of the world's attention focused on the debt crisis in Latin America during this period, another economic crisis was developing in Sub-Saharan Africa. Similar to Latin American nations, a number of African countries were facing the issue of debt servicing. Although the total international debt of African countries was far smaller than that of the Latin American region, the African economic crisis was much deeper than failing on the short-term financial obligations (Lancaster, 1983). The World Bank had issued several warnings that average income per capita on the African continent at the end of the 1980s, just over a decade after countries gained independence, was lower than at the beginning of the 1960s before African countries gained independence. On the political front, most important events were related to civil unrest. In 1985, Mahele Lieko Bokoungo fought back Congo's Laurent Kabila, who set up a rebel republic on the shores of Lake Tanganyika near Moba. In the same year, in Senegal, rebel fighters with the Movement of the Democratic Forces (MFDC) began a low-level insurgency against the government. In 1982, after two years of weak government and stagnant economy, the President, Hilla Limann, was ousted.

For the majority of countries, the early break appeared between the mid-1990s to late 1990s. This period was characterised by the Asian Financial Crisis (AFC). This financial upheaval first hit several developing Asian countries in mid-1997 and then quickly spread to other nations and became an international financial crisis that had a profound impact on many emerging markets. The AFC had influenced the African economies in a number of ways. In particular, it resulted in a period of highly volatile commodity prices, which reduced commodity demand and consequently decreased imports of commodities from Africa. For example, the drop in the gold price had seriously affected African gold producers (Ghana, South Africa and Zimbabwe); Botswana and South Africa were hurt by the decline in demand for diamonds; the fall in cotton prices had a major impact on $\operatorname{Togo}^{8}$. The sharp decline in

\footnotetext{
8 Please refer to the article "How has the Asian crisis affected other regions" on the IMF website at: http://www.imf.org/external/pubs/ft/fandd/1998/09/imfdirec.htm
} 
world oil prices had a severe negative influence on African net exporters of petroleum products (Angola, Cameroon, Gabon and Nigeria) for which the loss in export earnings was substantial. In addition, on average, the economic growth in Africa was low in both the 1980s and 1990s, a phenomenon referred to as "lost decades" of African development. The slower growth produced set-backs, especially via cuts to education and health expenditures, which have severe long-run consequences for future economic growth.

Between the early 2000s and 2010, 18 countries experienced structural break/s. The most important break can be attributed to the 2008 GFC which caused increased uncertainty and led to a vicious cycle of falling trade flows and investments. The food and fuel price shocks in mid-2008 left food-importing and oil-importing African countries under serious pressure, pushing down their foreign exchange reserves and creating an obstacle for them to afford their imports and to sustain economic growth. According to the $\mathrm{IMF}^{9}$, the majority of African countries consecutively suffered from food, fuel and financial $(3 \mathrm{~F})$ shocks at the time.

Overall, these results show that African nations are vulnerable to both internal and external shocks. As African countries continue their integration into the global economy (in particular, through China's activities in Africa), this vulnerability is likely to increase in future.

\section{Policy Implications}

Based on the results for the RALS-LM unit root tests, the relative energy consumption per capita is found to be divergent for four African countries including DR Congo, Senegal, Egypt and Botswana. Stochastic conditional divergence in energy consumption implies that those random shocks to energy consumption are likely to cause permanent departures from the current energy consumption path. Namely, a negative shock to energy, such as an adverse oil price shock, has the potential to have a permanent effect on these African nations and will lead to a persistent decline in productivity, output and a surge in unemployment that may worsen the existing poverty levels. Furthermore, a divergence in energy consumption per capita poses additional problems to the environment through the impossibility of converging to a common developing nation's greenhouse gas emissions levels, such as outlined by the Kyoto protocol. As a result, sound economic policies that promote equity in energy consumption are necessary to prevent adverse supply shocks and their detrimental macroeconomic and environmental consequences.

For the remaining African countries, energy consumption appears to be stationary indicating convergence in energy consumption levels. These countries increasingly rely on large levels of energy consumption to achieve economic growth, hence, understanding the energy dynamics is important for policy makers when developing policies for regional development, economic growth as well as developing emissions and renewable energy targets. Due to the finding of convergence for all income panels, the energy control target and greenhouse gas emissions targets should be different in different panels depending on the level of income. Specifically, the energy control target should not be too tight for both low income and lower middle income economies. Otherwise, the economic growth in these countries can be adversely affected because the necessary demand of energy consumption may not be

\footnotetext{
${ }^{9}$ IMF, Regional Economic Outlook - Sub-Saharan Africa, April 2009, Washington.
} 
satisfied. By contrast, it is reasonable to set stricter goals for upper middle income economies since these countries have the potential to control their energy consumption levels based on the rules of convergence.

In terms of catching up with China, the spread between African and Chinese energy consumption has been declining, indicating that, over time, African economies were increasing their energy consumption levels (i.e. converging). But these levels are still small compared to those of China. Note that over the past 20 years, China's energy use was growing, mostly due to the rise in consumption of fossil fuels which were either produced at home or imported. This growth took three decades to achieve. Only relatively recently has China started changing its energy mix towards renewables. In fact, China's GDP energy intensity (the ratio of energy consumption to GDP) was four times higher than the average of developed countries, and this statistic was even higher than some developing countries, such as Brazil and Mexico (Hao et al., 2015). To overcome its over-reliance on fossil fuels and promote greener economic growth, in the twenty-fifth "Five-year Plan" (2011-2015) the Chinese government has introduced limits to fossil fuel-based energy consumption to 40 million tons of standard coal.

\section{Conclusions}

Following Artadi and Sala-i-Martin (2003), dismal economic growth in Africa in the 20th century is one of the greatest tragedies, for the continent as a whole and for the world economy. This dismal growth in the past can be attributed to low education levels, poor health, harsh geographic conditions, closed economies, large scale public expenditure and large amounts of military conflicts (Artadi and Sala-i-Martin, 2003). The situation changed in the early 2000s (until the GFC) where countries started growing rapidly, on average 5\% or more (ADB, 2009). However, after the GFC, the drop of the commodity prices growth of African nations has been anaemic. It can be concluded that over the whole sample period, the performance of African nations has been uneven and depended on many factors, in particular energy consumption.

Due to the importance of energy consumption in achieving economic growth, this paper investigates stochastic conditional convergence in per capita energy consumption and the catch-up rate for 26 African countries; three panels split by the levels of income (lower income, lower middle income and upper middle income) using the conventional univariate and panel unit root tests as well as the latest advances in panel (Carrion-i-Silvestre et al. (2005) panel KPSS unit root test with multiple breaks; Pesaran (2007) CIPS panel unit root test) and time series (RALS-LM unit root tests with structural breaks) unit root techniques.

Our main findings are as follows. First, the results from the conventional panel unit root tests without structural breaks suggest there is divergence in both relative energy consumption per capita and catch-up rates for all panels. Nevertheless, panel unit root tests that take into account cross-sectional dependence and structural breaks provide strong evidence of convergence. Results of panel stationarity tests imply that ignoring the issue of cross-sectional dependence and structural breaks can give imprecise statistical inference. Second, based on the Carrion-i-Silvestre et al. (2005) panel KPSS unit root test with multiple breaks results we conclude that the impact of shocks on per capita energy consumption levels 
is likely to be temporary, which serves as evidence in favour of convergence. This has implications for formulating regional economic policies. Third, results of univariate RALSLM unit root tests with structural breaks confirm the findings of Carrion-i-Silvestre et al. (2005) panel KPSS tests. That is, there is convergence in per capita energy consumption and catch-up rate for most of the countries in the sample. Fourth, depending on a country, RALSLM tests suggest up to two structural breaks. These structural breaks included events external to Africa (e.g. AFC and GFC) as well as the internal shocks linked to specific economies. Most of these shocks could have occurred due to domestic political issues such as civil unrests and major country elections. Fifth, for several countries (DR Congo, Senegal, Egypt and Botswana) we found divergence in relative energy consumption per capita from the panel average. There is no evidence showing that these countries in the region will converge to the group average in the near future. Therefore, the presence of poverty and income inequality in these nations does not only cause per capita energy consumption divergence, but affects the per capita energy consumption disparity in the region. Sixth, results suggest that almost half of the African countries are found to share a common, steady energy consumption path with the energy consumption level of China. This shows that 26 African countries are likely to follow in China's footsteps by increasing energy use in order to achieve economic growth and reduce energy poverty. In particular, the African continent faces major electrification challenges. The shortage of electricity acts as a severe constraint to better living standards and economic growth. According to the IEA (2014, p. 3), because of the rapid population growth approximately one billion people in sub-Saharan Africa are projected to gain access to electricity by 2040, but more than half a billion people (mainly in rural areas) as compared to 600 million in 2014 are projected to remain without electricity. This would mean an improvement in the lives of 100 million people who do not have access to electricity. Due to immense financial constraints, individual country efforts should be accompanied by international efforts, such as the World Bank's Lighting Africa off-grid solar project as well as the financial or technical investments of foreign countries such as China. China, through its state-owned enterprises, has invested substantially in Africa as a strategy to expand international investments and gain access to foreign markets. In recent years, African economies relied heavily on China to support the expansion of their electricity systems, to boost economic growth and improve living conditions. Over half of the projects are based on renewable energy, mainly hydropower.

According to the African Development Bank (2017), many African nations in the sample (e.g. Sub-Saharan) need industrialisation to help them to grow faster in the future. Because the countries are so diverse, with different economic drivers, the pathways to industrialisation for the countries requiring it will be different. Irrespective of the industrialisation paths and unlike the Chinese experience of using fossil fuels in its economic development, governments of African nations should promote "green industrialisation" which allows achieving economic growth at lower environmental costs (ADB, 2017). The switch to greener energy sources is also important from the global warming perspectives. As compared to other developing countries, Africa has an advantage in terms of hydro, geothermal, wind and biomass resources as well as the tremendous untapped solar power potential. In particular, technical solar PV generation capacity for the entire continent is 300,000 gigawatts GW, while current installed capacity is only $150 \mathrm{GW}$ (Miketa and Saadi, 2015). Total technical wind potential is also vast - it is estimated to be above $7000 \mathrm{GW}$, but wind resources are not 
evenly distributed with high quality resources found only in half of the African countries (Miketa and Saadi, 2015).

Africa has an important task ahead - to achieve high levels of economic development through industrialisation and changing its energy mix towards renewables. In terms of the Rostow's (1962) development model, many African nations need to jump from agrarian states with limited manufacturing and extractive industries to post-industrial society. This giant leap cannot be achieved quickly by individual countries but by the joint work through developing regional blocks and acquiring help from developed nations in terms of technological advancements and financial help. China is contributing immensely to the economic development in Africa through investing in the priority energy sector, accounting for $30 \%$ of new capacity additions in the Sub-Saharan region ${ }^{10}$. In addition, the stability of energy supply is crucial for the sustainable growth of the African economies.

Our finding of stochastic convergence for most countries in the sample implies that joint policies with respect to energy are likely to contribute towards the common level. In addition, the impact of shocks is likely to be temporary, meaning that Africa will rebound from economic hardships, although this might take time. There are several avenues for future research. For instance, this paper focused on stochastic convergence in per capita energy consumption among African nations. It would be interesting to study other forms of convergence such as absolute and club convergence because they would highlight other properties of convergence in energy consumption. In addition, events proposed in the paper as potential causes of breaks need to be investigated further in terms of their magnitude, direction and duration of impact. This will allow classifying the impact of different events (domestic vs external, terms of trade shocks vs production or financial shocks). Future research could investigate energy convergence at the state level within countries. Following Apergis and Christou (2016), future research could use stationarity tests to examine convergence in energy productivity or energy intensity. In addition, as an extension of the work presented in this article, it would be interesting to model the catch-up rate, the speed of convergence with Chinese energy consumption and the factors that could affect this convergence.

\section{References}

African Development Bank (2009). Africa in the wake of the Global Financial Crisis: Challenges ahead and the role of the Bank. Polciy brief. Available online at: https://www.afdb.org/fileadmin/uploads/afdb/Documents/Publications/Africa\%20in\%20the\%20wake\% 20of\%20the\%20crisis\%20-\%20English\%20-

\%20Jan\%2020_corrected\%20March\%2023\%202010\%20A.pdf

\footnotetext{
10 refer to the website of the International Energy Agency (IEA): https://www.iea.org/newsroom/news/2016/july/new-iea-report-maps-chinese-investments-in-africas-powersector.html
} 
African Development Bank (2017). African Economic Outlook 2017: Entrepreneurship and Industrialization. Available online at: http://dx.doi.org/10.1787/aeo-2017-en

Apergis, N. \& Payne, J, E. (2010). Structural breaks and petroleum consumption in US states: Are shocks transitory or permanent? Energy Policy, 38, 6375-6378.

Alper, A. \& Hakan, K. (2011). The stationarity of energy consumption for Turkish disaggregate data by employing linear and nonlinear unit root tests. Energy, 36(7), 4256-4258.

Agnolucci, P. \& Venn, A. (2011). Industrial energy intensities in the UK: Is there a deterministic or stochastic difference among sectors? Applied Economics, 43, 1447-1462.

Acaravci, A. \& Erdogan, S. (2016). The convergence behaviour of $\mathrm{CO}_{2}$ emissions in seven regions under multiple structural breaks. International Journal of Energy Economics Policy, 6(3), 575-580.

Anorou, E. \& DiPietro, W, R. (2014). Convergence in per capita energy consumption among African countries: Evidence from a sequential panel selection method. International Journal of Energy Economics and Policy, 4(4), 568-577.

Artadi, E.V. \& Sala-i-Martin, X. (2003). The economic tragedy of the XXth century: growth in Africa. NBER Working Paper, vol. 9865.

Apergis, N. \& Christou, C. (2016). Enegy productivity convergence: new evidence from club converging. Applied Economics Letters, 23(2), 142-145.

Belke, A., Dobnik, F. \& Dreger, C. (2011). Energy consumption and economic growth: New insights into the cointegration relationship. Energy Economics, 33(5), 782-789.

Barro, R. \& Sala-i-Martin, X. (1991). Convergence across states and regions. Brookings Papers on Economic Activity, no. 1, 107-182.

Barro, R. \& Sala-i-Martin, X. (2004). Economic Growth, The MIT Press, London.

Banerjee, A., Marcellino, M. \& Osbat, C. (2005). Testing for PPP: Should we use panel methods? Empirical Economics, 30, 70-91.

Bai, J. \& Ng, S. (2004). A panic attack on unit roots and cointegration. Econometrica, 72(4), 1127-1177.

Bai, J. \& Perron, P. (1998). Estimating and testing linear models with multiple structural changes. Econometrica, 66, 47-78.

Bai, J. \& Perron, P. (2005). Multiple strcutral change models: a simulation analysis, in Corbae, P.D., Durlauf, S.N. \& Hansen, B.E. (eds.): Econometric Theory and Pratice. Frontier Analysis and Applied Research. Cambridge University Press.

Bacon, R. \& Mattar, A. (2005). The vunerability of African countries to oil price shocks: major factors and policy options, the case of oil importing countries. Energy Sector Magament Assisstance Program Working Paper Series, ESM 308/05. World Bank, Washington, DC.

Costanti, M. \& Claudio, L. (2014). Identifying I(0) series in Macro-panels: Are sequential panel selection methods useful? Economics and Statistic Disucussion Papers No. 073/14. University of Molise.

Carrion-i-Silvestre, J,L., Barrio-Castro, T,D. \& Lopez-Bazo, E. (2005). Breaking the panels: An application to GDP per capita. Journal of Econometrics, 8, 159-175.

Carrion-i-Silvestre, J.L. (2005). Health care expenditure and GDP: are they broken stationary? Journal of Health Economics, 24, 839-854.

Djennas, M. \& Ferouani, B. (2014). Growth and income convergence in Africa. Journal of Economics and Development Studies, 2(4), 63-76.

Fallahi, F. (2017). Stochastic convergence in per capita energy use in world. Energy Economics, 65, 228-239. 
Galor, O. (1996). Convergence? Inferences from theoretical models. The Economic Journal, 106(437), 10561069.

Hasanov, M. \& Telatar, E. (2011). A re-examination of stationarity of energy consumption: Evidence from new unit root tests. Energy Policy, 39, 7726-7738.

Hadri, K. (2000). Testing for stationarity in heterogeneous panel data. Econometrics Journal, 3, 148-161.

Hao, Y., Wang, S. \& Zhang, Z. (2015). Examine the convergence in per capit energy consumption in China with breakpoints. Energy Procedia, 75, 2617-2625.

Herrerias, M.J., Aller, C. \& Ordóñez, J. (2017). Residential energy consumption: A convergence analysis across Chinese regions. Energy Economics, 62, 371-381.

International Energy Agency (2014). Africa Energy Outlook. World Energy Outlook Special Report. Availabe online at: https://www.iea.org/publications/freepublications/publication/WEO2014_AfricaEnergyOutlook.pdfIm, K.S. \& Schmidt, P. (2008). More efficient estimation under non-normality when higher moments do not depend on the regressors, using residual augmented least squares. Journal of Econometrics, 144, 219-233.

Khan, F. A. (2014). Economic Convergence in the African Continent: Closing the Gap. South African Journal of Economics, 82, 354-370.

Kruse, R. (2011). A new unit root test agaisnt ESTAR based on a class of modified statistics. Statistical Papers, 57, 71-85.

Kwiatkowski, D., Phillips, P.C.B., Schmidt, P. \& Shin, Y. (1992). Testing the null of stationarity against the alternative of a unit root: how sure are we that economic time series have a unit root? Journal of Econometrics, 54(1-3), 159-178.

Kejriwal, M. \& Perron, P. (2010). A sequential procedure to determine the number of breaks in trend with an integrated or stationary noise component. Journal of Time Series Analysis, 31(5), 305-328.

Lee, J. \& Strazicich, M, C. (2003). Minimum LM unit root test with two structural breaks. Review of Economics and Statistics, 85(4), 1082-1089.

Lean, H.H., Mishra, V. \& Smyth, R. (2016). Conditional convergence in US disaggregated petroleum consumption at the sector level. Applied Economics, 48(32), 3049-3061.

Levin, A., Lin, C.F. \& Chu, C-S, J. (2002). Unit root tests in panel data: asympototic and finite sample properties. Journal of Econometrics, 108, 1-22.

Lancaster, C. (1983). Africa’s economic crisis. Foreign Policy, 52, 149-166.

Miketa, A. \& Saadi, N. (2015). Africa Power Sector: planning and prospectus for renewable energy (synthethis report). International Renewable Energy Agency report. Available online at: https://www.irena.org/documentdownloads/Publications/IRENA_Africa_Power_Sector_synethesis_20 15.pdf

Mohammadi, H. \& Ram, R. (2012). Cross-country convergence in energy and electricity consumption, 19712007. Energy Economics, 34(6), 1882-1887.

Mohammadi, H., Ram, R., 2017. Convergence in energy consumption per capita across the US states, 19702013: An exploration through selected parametric and non-parametric methods. Energy Economics. 62, 404-410.

Meng, M., Payne, J.E. \& Lee, J. (2013). Convergence in per capita energy use among OECD countries consumption. Energy Economics, 36, 536-545. 
Mohammadi, H. \& Ram, R. (2017). Covergence in energy consumption per capita across the US states, 19702013: An exploration through selected parametric and non-parametric methods. Energy Economics, 62(C), 404-410.

Mishra, V. \& Smyth, R. (2017). Conditonal convergence in Australia's energy consumpton at the sector level. Energy Economics, 62, 396-403.

Mishra, V. \& Smyth, R. (2014). Convergence in energy consumption per capita among ASEAN countries. Energy Policy, 73, 180-185.

Meng, M., Payne, J, E. \& Lee, J. (2013). Convergence in per capita Energy Use among OECD Countries, Energy Economics, 36, 536-45.

Maddala, G, S. \& Wu, S. (1999). A comparative study of unit roots with panel data and a new simple test. Oxford Bulletin of Economics and Statistics, 61, 631-651.

Meng, M., IM, K.S., Lee, J. \& Tieslau, M.A. (2014). More powerful LM unit root tests with non-normal errors. In: Sickles, R.C., Horrace, W.C.(Eds.), Festschrift in Honour of Peter Schmidt. Springer, New York, 343-357.

Narayan, P, K. \& Smyth, R.. (2007). Are shocks to energy consumption permanent or temporary? Evidence from 182 countries. Energy Policy, 35, 333-341.

Narayan, P, K., Narayan, S. \& Popp, S. (2010). Energy consumption at the state level: the unit root null hypothesis from Australia. Applied Energy, 87, 1953-1962.

Narayan, P, K. \& Popp, S. (2010). A new unit root test with two structural breaks in level and slope at unknown time. Journal of Applied Statistics, 37, 1425-1438.

Öztürk, I., Aslan, A. \& Kalyoncu, H. (2010). Energy consumption and economic growth relationship: Evidence from panel data for low and middle income countries. Energy Policy, 38(8), 4422-4428.

Öztürk, I. \& Aslan, A. (2015). Are fluctuations in electricity consumption permanent or transitory? Evidence from a nonlinear unit root test in High-income OECD countries. Energy Sources, Part B: Economics, Planning, and Policy, 10(3), 257-262.

Oyuke, A., Penar, P.H. \& Howard, B. (2016). Off-grid or 'off-on': Lack of access, unreliable electricity supply still plague majority of Africans. Afrobarometer research paper no. 75, available online at: http://afrobarometer.org/sites/default/files/publications/Dispatches/ab_r6_dispatchno75_electricity_in_ africa_eng1.pdf

Payne, J, E., Vizek, M. \& Lee, J. (2017). Stochastic convergence in per capita fossil fuel consumption in US states. Energy Economics, 62, 380-393.

Pesaran, M. (2004). General diagonostic tests for cross section dependence in panels. Institute for the Study of Labor (IZA), IZA Discussion Paper 1240.

Pesaran, M. (2007). A simple unit root test in the presence of cross-section dependence. Journal of Applied Econometrics, 22, 265-312.

Perron, P. \& Yabu, T. (2009). Testing for shifts in trend with an integrated or stationary noise component. Journal of Business \& Economic Statistics, 27, 369-396.

Ranjabar, O., Lee, C.-C., Chang, T. \& Chen, M.-P. (2014). Income convergence in African countries: Evidence from a stationary test with multiple structural breaks. South African Journal of Economics, 82, 371391.

Rostow, W.W. (1962). The Stages of Economic Growth. London: Cambridge University Press.

Shahbaz, M., Tiwari, A, K. \& Khan, S. (2016). Is energy consumption per capita stationary? Evidence from first and second generation panel unit root tests. Economics Bulletin, 36(3), 1656-1669. 
Solow, R.M. (1956). A contribution to the theory of economic growth. The Quarterly Journal of Economics, $70(1), 65-94$

Strazicich, M.C., Lee, J. \& Day, E. (2004). Are incomes converging among OECD Countries? Time series evidence with two structural breaks. Journal of Macroeconomics, 26(1), 131-145.

Sy, A. (2016). Is Africa at a historical crossroads to convergence? In THINK TANK 20: Growth, convergence and income distribution: the road from the Brisbane G-20 Summit. Available online at: https://www.brookings.edu/wp-content/uploads/2016/07/tt20-africa-convergence-sy.pdf

Tsani, S. (2017). Energy consumption and economic growth: A causality analysis for Greece. Energy Economics, 32(3), 582-590.

Yuan, J., Kang, J., Zhao, C. \& Hu, Z. (2008). Energy consumption and economic growth: Evidence from China at both aggregated and disaggregated levels. Energy Economics, 30(6), 3077-3094.

World Bank (2017). Factsheet: The World Bank and Energy in Africa. Available online at: http://web.worldbank.org/WBSITE/EXTERNAL/COUNTRIES/AFRICAEXT/0,,contentMDK:219355 94 pagePK:146736 piPK:146830 theSitePK:258644,00.html 


\section{Tables and Figures}

Table 1: Recent studies on convergence in energy consumption

\begin{tabular}{|c|c|c|c|c|c|}
\hline Study & Methodology & Period & Country & Energy Type & Findings \\
\hline Meng et al. (2013) & LM, RALS-LM & $1960-2010$ & 25 OECD countries & Energy consumption per capita & Convergence \\
\hline Mishra and Smyth (2014) & $\begin{array}{l}\text { Carrion et al. (2005) panel KPSS, } \\
\text { Im et al. (2005) panel LM }\end{array}$ & $1971-2011$ & ASEAN-5 & Energy consumption per capita & Convergence \\
\hline Anoruo and DiPietro (2014) & $\begin{array}{l}\text { Conventional panel unit root, } \\
\text { SPSM }\end{array}$ & $1971-2011$ & 22 African countries & Energy consumption per capita & $\begin{array}{l}\text { Convergence } \\
\text { Convergence }\end{array}$ \\
\hline Shahbaz et al. (2016) & Conventional panel unit root & $1971-2010$ & 103 countries & Energy consumption per capita & Convergence \\
\hline Lean et al. (2016) & GRACH unit root test with breaks & $1973-2014$ & 5 sectors in US & Petroleum consumption & $\begin{array}{l}\text { Mixed } \\
\text { Evidence }\end{array}$ \\
\hline Fallahi (2017) & Subsampling confidence intervals & $1971-2013$ & 109 countries & Energy consumption per capita & Convergence \\
\hline Herrerias et al. (2017) & Phillips-Sul club convergence & $1995-2011$ & Chinese regions & $\begin{array}{l}\text { Regional energy consumption } \\
\text { (coal, liquid gas and electricity) }\end{array}$ & $\begin{array}{l}\text { Rional converge } \\
\text { clusters }\end{array}$ \\
\hline Mishra and Smyth (2017) & LM, RALS-LM & $\begin{array}{l}1973-74 \text { to } \\
2013-14\end{array}$ & $\begin{array}{l}\text { Industry sectors in } \\
\text { Australia }\end{array}$ & Energy consumption & $\begin{array}{l}\text { Convergence } \\
\text { across sectors }\end{array}$ \\
\hline Mohammadi and Ram (2017) & $\begin{array}{l}\text { Maddala and Wu (1999), } \\
\text { Pesaran (2007) CIPS test }\end{array}$ & $1970-2013$ & 48 US states & Energy consumption per capita & $\begin{array}{l}\text { No stochastic } \\
\text { convergence, but } \\
\text { gamma } \\
\text { convergence } \\
\text { exists }\end{array}$ \\
\hline Payne et al. (2017) & LM, RALS-LM & $1970-2013$ & All US states & Fossil fuel consumption per capita & Convergence \\
\hline
\end{tabular}


Table 2: Sample classifications based on income levels

\begin{tabular}{lll}
\hline Country & World Bank country code & Geographic Region \\
\hline \multicolumn{2}{l}{ Panel A: Low income economies } & \\
Benin & BEN & Sub-Saharan Africa \\
Congo, Dem. Rep. & COD & Sub-Saharan Africa \\
Ethiopia & ETH & Sub-Saharan Africa \\
Mozambique & MOZ & Sub-Saharan Africa \\
Senegal & SEN & Sub-Saharan Africa \\
Togo & TGO & Sub-Saharan Africa \\
Tanzania & TZA & Sub-Saharan Africa \\
Zimbabwe & ZWE & Sub-Saharan Africa
\end{tabular}

Panel B: Lower middle-income economies

$\begin{array}{lll}\text { Angola } & \text { AGO } & \text { Sub-Saharan Africa } \\ \text { Cote d'Ivoire } & \text { CIV } & \text { Sub-Saharan Africa } \\ \text { Cameroon } & \text { CMR } & \text { Sub-Saharan Africa } \\ \text { Congo, Rep. } & \text { COG } & \text { Sub-Saharan Africa } \\ \text { Egypt } & \text { EGY } & \text { Middle East \& North Africa } \\ \text { Ghana } & \text { GHA } & \text { Sub-Saharan Africa } \\ \text { Kenya } & \text { KEN } & \text { Sub-Saharan Africa } \\ \text { Morocco } & \text { MAR } & \text { Middle East \& North Africa } \\ \text { Nigeria } & \text { NGA } & \text { Sub-Saharan Africa } \\ \text { Sudan } & \text { SDN } & \text { Sub-Saharan Africa } \\ \text { Tunisia } & \text { TUN } & \text { Middle East \& North Africa } \\ \text { Zambia } & \text { ZMB } & \text { Sub-Saharan Africa }\end{array}$

Panel C: Upper middle-income economies

\begin{tabular}{lll} 
Algeria & DZA & Middle East \& North Africa \\
Botswana & BWA & Sub-Saharan Africa \\
Gabon & GAB & Sub-Saharan Africa \\
Libya & LBY & Middle East \& North Africa \\
Mauritius & MUS & Sub-Saharan Africa \\
South Africa & ZAF & Sub-Saharan Africa \\
\hline Notes: Regions in this table are based on the classification criteria from the World Bank.
\end{tabular}


Table 3: Descriptive statistics of relative per capita energy consumption ( $\mathrm{kg}$ of oil equivalent per capita) for different economies in Africa

\begin{tabular}{|c|c|c|c|c|c|c|c|}
\hline Country & Obs. & Mean & Std.Dev & Min & Max & Skewness & Kurtosis \\
\hline \multicolumn{8}{|c|}{ Panel A: Low income economies } \\
\hline Benin & 44 & -0.221 & 0.073 & -0.368 & -0.007 & 0.665 & 3.383 \\
\hline Congo, Dem. Rep. & 44 & -0.312 & 0.071 & -0.451 & -0.074 & 0.745 & 4.732 \\
\hline Ethiopia & 44 & 0.082 & 0.063 & -0.069 & 0.169 & -1.050 & 3.113 \\
\hline Mozambique & 44 & 0.067 & 0.139 & -0.108 & 0.367 & 0.665 & 2.108 \\
\hline Senegal & 44 & -0.553 & 0.080 & -0.693 & -0.373 & 0.271 & 2.810 \\
\hline Togo & 44 & -0.180 & 0.178 & -0.444 & 0.123 & 0.084 & 1.480 \\
\hline Tanzania & 44 & -0.040 & 0.071 & -0.153 & 0.125 & 0.122 & 1.970 \\
\hline Zimbabwe & 43 & 0.652 & 0.098 & 0.419 & 0.803 & -0.946 & 2.948 \\
\hline \multicolumn{8}{|c|}{ Panel B: Lower middle-income economies } \\
\hline Angola & 44 & 0.006 & 0.111 & -0.185 & 0.279 & 0.910 & 3.153 \\
\hline Cote d'Ivoire & 44 & -0.117 & 0.116 & -0.288 & 0.065 & 0.047 & 1.416 \\
\hline Cameroon & 44 & -0.185 & 0.159 & -0.576 & -0.043 & -1.377 & 3.440 \\
\hline Cong, Rep. & 44 & -0.382 & 0.192 & -0.760 & -0.052 & -0.368 & 2.288 \\
\hline Egypt & 44 & 0.067 & 0361 & -0.729 & 0.519 & -0.866 & 2.610 \\
\hline Ghana & 44 & -0.341 & 0.173 & -0.687 & -0.146 & -0.721 & 1.959 \\
\hline Kenya & 44 & -0.066 & 0.071 & -0.234 & 0.049 & -0.540 & 2.355 \\
\hline Morocco & 44 & -0.359 & 0.244 & -0.872 & -0.009 & -0.220 & 2.022 \\
\hline Nigeria & 44 & 0.361 & 0.042 & 0.280 & 0.427 & -0.388 & 2.051 \\
\hline Sudan & 44 & -0.171 & 0.154 & -0.476 & 0.128 & -0.168 & 2.394 \\
\hline Tunisia & 44 & 0.246 & 0.244 & -0.300 & 0.565 & -0.637 & 2.374 \\
\hline Zambia & 43 & 0.356 & 0.193 & 0.060 & 0.685 & 0.119 & 1.831 \\
\hline \multicolumn{8}{|c|}{ Panel C: Upper middle-income economies } \\
\hline Algeria & 44 & -0.723 & 0.299 & -1.486 & -0.397 & -1.425 & 3.673 \\
\hline Botswana & 34 & -0.552 & 0.106 & -0.740 & -0.371 & -0.206 & 1.915 \\
\hline Gabon & 44 & 0.153 & 0.270 & -0.264 & 0.655 & -0.014 & 1.747 \\
\hline Libya & 44 & 0.415 & 0.253 & -0.373 & 0.666 & -1.421 & 4.209 \\
\hline Mauritius & 44 & -0.850 & 0.227 & -1.277 & -0.512 & -0.361 & 1.816 \\
\hline South Africa & 44 & 0.478 & 0.090 & 0.256 & 0.653 & -0.388 & 2.757 \\
\hline
\end{tabular}


Table 4: The catch-up rate and growth rate of catch-up in African economies

\begin{tabular}{|c|c|c|c|c|}
\hline \multirow[t]{2}{*}{ Country } & \multicolumn{3}{|c|}{ Catch-up rate } & \multirow{2}{*}{$\begin{array}{c}\text { Catch-up Growth rate } \\
\text { Mean }\end{array}$} \\
\hline & Mean & Min & Max & \\
\hline \multicolumn{5}{|c|}{ Panel A: Low income economies } \\
\hline Benin & -0.913 & -1.695 & -0.225 & -0.034 \\
\hline Congo, Dem. Rep. & -1.004 & -1.888 & -0.359 & -0.032 \\
\hline Ethiopia & -0.609 & -1.505 & 0.023 & -0.036 \\
\hline Mozambique & -0.625 & -1.678 & 0.459 & -0.049 \\
\hline Senegal & -1.245 & -2.131 & -0.497 & -0.037 \\
\hline Togo & -0.872 & -1.589 & -0.335 & -0.029 \\
\hline Tanzania & -0.732 & -1.549 & 0.149 & -0.039 \\
\hline Zimbabwe & -0.017 & -1.083 & 0.782 & -0.044 \\
\hline \multicolumn{5}{|c|}{ Panel B: Lower middle-income economies } \\
\hline Angola & -0.593 & -1.422 & 0.203 & -0.037 \\
\hline Cote d'Ivoire & -0.716 & -1.367 & -0.037 & -0.029 \\
\hline Cameroon & -0.784 & -1.885 & -0.144 & -0.040 \\
\hline Cong, Rep. & -0.981 & -1.638 & -0.252 & -0.027 \\
\hline Egypt & -0.532 & -1.010 & -0.252 & -0.006 \\
\hline Ghana & -0.940 & -1.898 & -0.279 & -0.037 \\
\hline Kenya & -0.665 & -1.540 & -0.024 & -0.034 \\
\hline Morocco & -0.958 & -1.397 & -0.796 & -0.011 \\
\hline Nigeria & -0.238 & -1.075 & 0.220 & -0.030 \\
\hline Sudan & -0.770 & -1.782 & 0.055 & -0.042 \\
\hline Tunisia & -0.353 & -0.863 & -0.134 & -0.011 \\
\hline Zambia & -0.226 & -1.248 & 0.596 & -0.044 \\
\hline
\end{tabular}

Panel C: Upper middle-income economies

\begin{tabular}{lcccc} 
Algeria & -0.169 & -0.697 & 0.262 & 0.004 \\
Botswana & -0.084 & -0.727 & 0.266 & -0.017 \\
Gabon & 0.707 & -0.043 & 1.626 & -0.027 \\
Libya & 0.968 & 0.057 & 1.380 & -0.004 \\
Mauritius & -0.297 & -0.704 & -0.046 & -0.015 \\
South Africa & 1.031 & 0.169 & 1.442 & -0.029 \\
\hline
\end{tabular}

Notes: Catch-up rate is defined as $X_{i, t}=\log \left(G_{i, t} / G_{\text {china,t }}\right)$ where $G_{i, t}$ is the per capita energy consumption of country $i$ in year $t$ and $G_{\text {china,t }}$ represents the per capita energy consumption of China. Catch-up growth rate is calculated as: $g_{i, t}=X_{i, t}-X_{i, t-1}$. 
Table 5: Cross-section correlation of the errors in the $\operatorname{ADF}(p)$ regression

\begin{tabular}{lcccc}
\hline \multicolumn{1}{l}{ Economies } & $\mathrm{p}=1$ & $\mathrm{p}=2$ & $\mathrm{p}=3$ & $\mathrm{p}=4$ \\
\hline \multicolumn{2}{l}{ Panel A: Low income economies } & & & \\
\multicolumn{2}{l}{ Actual energy consumption per capita } & & & \\
$\overline{\hat{\rho}}$ & 0.028 & 0.028 & 0.027 & 0.025 \\
$\mathrm{CD}$ & 0.920 & 0.933 & 0.898 & 0.825 \\
Relative energy consumption per capita & & & \\
$\overline{\hat{\rho}}$ & -0.083 & -0.080 & -0.080 & -0.078 \\
$\mathrm{CD}$ & $-2.741^{* * *}$ & $-2.648^{* * *}$ & $-2.627^{* * *}$ & $-2.589^{* * *}$
\end{tabular}

Panel B: Lower middle-income economies

Actual energy consumption per capita

$\begin{array}{lllll}\overline{\hat{\rho}} & 0.028 & 0.011 & 0.020 & 0.021 \\ \mathrm{CD} & 1.440 & 0.534 & 1.018 & 1.081\end{array}$

Relative energy consumption per capita

$\begin{array}{lcccc}\overline{\hat{\rho}} & -0.066 & -0.063 & -0.060 & -0.058 \\ \mathrm{CD} & -3.374 * * * & -3.192 * * * & -3.038 * * * & -2.921 * * *\end{array}$

$\mathrm{CD}$

$-3.374 * * *$

$-3.192 * * *$

$-3.038 * * *$

$-2.921 * * *$

Panel C: Upper middle-income economies

Actual energy consumption per capita

$\begin{array}{lcccc}\overline{\hat{\rho}} & 0.131 & 0.160 & 0.154 & 0.150 \\ \mathrm{CD} & 3.284 * * * & 4.005^{* * *} & 3.864 * * * & 3.771 * * * \\ \text { Relative energy consumption per capita } & & & \\ \overline{\hat{\rho}} & -0.122 & -0.115 & -0.107 & -0.103 \\ \mathrm{CD} & -3.052^{* * *} & -2.875^{* * *} & -2.687 * * * & -2.575^{* * *}\end{array}$

Panel D: Catch-up rate for low income economies

$\begin{array}{lcccc}\overline{\hat{\rho}} & 0.587 & 0.510 & 0.508 & 0.509 \\ \mathrm{CD} & 19.405^{* * *} & 16.843^{* * * *} & 16.802 * * * & 16.822^{* * *}\end{array}$

Panel E: Catch-up rate for lower middle- income economies

$\begin{array}{lcccc}\overline{\hat{\rho}} & 0.425 & 0.417 & 0.409 & 0.399 \\ \mathrm{CD} & 21.586^{* * * *} & 21.144^{* * * *} & 20.776^{* * * *} & 20.224 * * *\end{array}$

Panel F: Catch-up rate for upper middle- income economies
$\overline{\hat{\rho}}$
0.289
0.245
0.242
0.238
$\mathrm{CD}$
$6.123 * * *$
$5.208 * * *$
$5.131 * * *$
$5.057 * * *$

Notes: The cross-sectional dependence (CD) test is developed by Pesaran (2004) for testing crosssectional dependence in panels. All statistics are based on univariate $\operatorname{AR}(p)$ specifications in the level and trend of the variables with $p \leq 4$. The null hypothesis is that output innovations are crosssectionally independent. The CD test statistic follows a $N(0,1)$ distributions. The $10 \%, 5 \%$ and $1 \%$ critical values for the $\mathrm{CD}$ statistic are $1.64,1.96$ and 2.57 respectively. $* * *$ denotes statistical significance at the $1 \%$ level. 
Table 6: Pesaran (2007) CIPS panel unit root test results

\begin{tabular}{lcccc}
\hline Economies & $\mathrm{p}=1$ & $\mathrm{p}=2$ & $\mathrm{p}=3$ & $\mathrm{p}=4$ \\
\hline Panel A: Energy consumption per capita & & & & \\
Low income economies & -2.158 & -2.314 & -2.336 & -2.418 \\
Lower middle-income economies & -2.515 & -2.322 & -2.372 & -2.535 \\
Upper middle-income economies & -2.554 & -2.225 & -1.595 & -1.473 \\
& & & & \\
Panel B: Catch-up rate & & & & \\
Low income economies & -1.809 & -1.780 & -1.363 & -1.106 \\
Lower middle-income economies & $-3.083^{* * *}$ & -2.515 & -2.348 & -2.175 \\
Upper middle-income economies & -2.246 & -1.95 & -1.443 & -1.448 \\
\hline
\end{tabular}

Notes: The test is performed under the assumption that there is an intercept and linear trend in the series (Case 3 in Pesaran, 2007). For the low income economies and upper middle-income economies, the $10 \%, 5 \%$ and $1 \%$ critical values for Case 3 with $T=50, N=10$ from Pesaran (2007) are -2.73 , 2.84 and -3.06 , respectively. For the lower middle-income economies, the $10 \%, 5 \%$ and $1 \%$ critical values for Case 3 with $T=50, N=15$ from Pesaran (2007) are -2.66, -2.76 and -2.93 , respectively. $* * *$ denotes statistical significance at the $1 \%$ level. 
Table 7: Panel KPSS test with multiple structural breaks

\begin{tabular}{|c|c|c|c|c|c|}
\hline \multirow[t]{2}{*}{ Economies } & \multirow{2}{*}{$\begin{array}{l}\text { KPSS test statistic } \\
\text { (using Bartlett kernel) }\end{array}$} & \multicolumn{4}{|c|}{ Bootstrap critical values } \\
\hline & & $90 \%$ & $95 \%$ & $97.5 \%$ & $99 \%$ \\
\hline \multicolumn{6}{|c|}{ Panel A: Low income economies } \\
\hline Breaks (Homogeneous) & 5.251 & 7.495 & 8.692 & 9.667 & 11.207 \\
\hline Breaks (Heterogeneous) & 22.136 & 20.891 & 24.065 & 27.615 & 31.689 \\
\hline \multicolumn{6}{|c|}{ Panel B: Lower middle-income economies } \\
\hline Breaks (Homogeneous) & 6.730 & 15.039 & 16.022 & 17.135 & 18.183 \\
\hline Breaks (Heterogeneous) & 7.901 & 17.519 & 18.698 & 19.667 & 20.775 \\
\hline \multicolumn{6}{|c|}{ Panel C: Upper middle-income economies } \\
\hline Breaks (Homogeneous) & 11.268 & 12.616 & 16.204 & 20.710 & 26.913 \\
\hline Breaks (Heterogeneous) & 33.385 & 31.006 & 35.275 & 40.456 & 46.393 \\
\hline \multicolumn{6}{|c|}{ Panel D: Catch-up rate for low income economies } \\
\hline Breaks (Homogeneous) & 3.665 & 13.010 & 15.502 & 17.662 & 20.967 \\
\hline Breaks (Heterogeneous) & 25.690 & 35.447 & 41.550 & 47.151 & 55.783 \\
\hline \multicolumn{6}{|c|}{ Panel E: Catch-up rate for lower middle-income economies } \\
\hline Breaks (Homogeneous) & 4.302 & 12.380 & 13.296 & 14.167 & 15.147 \\
\hline Breaks (Heterogeneous) & 9.582 & 17.055 & 18.686 & 20.025 & 21.163 \\
\hline \multicolumn{6}{|c|}{ Panel $\mathbf{F}$ : Catch-up rate of upper middle-income economies } \\
\hline Breaks (Homogeneous) & 2.739 & 7.930 & 9.476 & 13.003 & 17.329 \\
\hline Breaks (Heterogeneous) & 5.537 & 20.073 & 24.011 & 26.939 & 30.746 \\
\hline
\end{tabular}


Table 8: Pesaran (2007) time series CIPS unit root test results

\begin{tabular}{|c|c|c|c|c|}
\hline Economies & $\mathrm{p}=1$ & $\mathrm{p}=2$ & $\mathrm{p}=3$ & $\mathrm{p}=4$ \\
\hline \multicolumn{5}{|c|}{ Panel A: Low income economies } \\
\hline Benin & -2.612 & -2.647 & -2.649 & -2.539 \\
\hline Congo, Dem. Rep. & -0.428 & -1.139 & -1.590 & -1.180 \\
\hline Ethiopia & -2.056 & -1.466 & -0.817 & -1.198 \\
\hline Mozambique & -2.291 & -2.022 & -1.794 & -2.329 \\
\hline Senegal & -2.987 & -3.528 & -3.722 & $-4.103 *$ \\
\hline Togo & -2.421 & -2.971 & -3.641 & -3.545 \\
\hline Tanzania & -1.377 & -1.397 & -1.587 & -1.588 \\
\hline Zimbabwe & -3.092 & -3.339 & -3.068 & -2.860 \\
\hline \multicolumn{5}{|c|}{ Panel B: Lower middle-income economies } \\
\hline Angola & -3.192 & $-4.247 * *$ & -2.764 & -3.375 \\
\hline Cote d'Ivoire & -2.668 & -2.784 & -3.135 & $-4.135^{*}$ \\
\hline Cameroon & -1.075 & -1.369 & -2.214 & -2.001 \\
\hline Congo, Rep. & -1.205 & -0.364 & -0.992 & -1.539 \\
\hline Egypt & -0.684 & -1.319 & -1.551 & -0.958 \\
\hline Ghana & -2.043 & -2.078 & -1.875 & -1.938 \\
\hline Kenya & -2.615 & -2.288 & -2.752 & -2.763 \\
\hline Morocco & -2.649 & -2.702 & -2.511 & -2.772 \\
\hline Nigeria & -3.215 & -2.751 & -2.550 & -3.005 \\
\hline Sudan & -2.543 & -1.648 & -1.424 & -0.916 \\
\hline Tunisia & -3.443 & -2.731 & -3.381 & $-3.722 *$ \\
\hline Zambia & $-4.848 * *$ & -3.579 & -3.310 & -3.293 \\
\hline \multicolumn{5}{|c|}{ Panel C: Upper middle-income economies } \\
\hline Algeria & -1.506 & -0.591 & 0.071 & -0.088 \\
\hline Botswana & -1.999 & -1.863 & -1.630 & -1.386 \\
\hline Gabon & -2.326 & -1.876 & -2.098 & -2.318 \\
\hline Libya & -3.185 & -2.202 & -2.005 & -1.785 \\
\hline Mauritius & -1.042 & -0.711 & -0.726 & -0.818 \\
\hline South Africa & $-5.267 * *$ & $-6.109 * *$ & -3.183 & -2.446 \\
\hline \multicolumn{5}{|c|}{ Panel D: Catch-up rate for low income economies } \\
\hline Benin & $-4.198 *$ & $-4.540^{*}$ & $-4.247 *$ & -3.198 \\
\hline Congo, Dem. Rep. & -1.033 & -1.183 & -1.232 & -0.716 \\
\hline Ethiopia & -1.316 & -0.726 & 0.025 & -0.330 \\
\hline Mozambique & -2.002 & -1.062 & 0.647 & 0.399 \\
\hline Senegal & -1.306 & -1.601 & -1.697 & -2.165 \\
\hline Togo & -2.495 & -2.646 & -2.405 & -1.614 \\
\hline Tanzania & -1.033 & -0.626 & -0.522 & -0.307 \\
\hline Zimbabwe & -1.091 & -1.854 & -1.475 & -0.921 \\
\hline
\end{tabular}

Continued on next page 
Table 8 - Continued from previous page

\begin{tabular}{lcccc}
\hline Panel E: Catch-up rate for lower middle-income economies & & \\
Angola & $-3.676^{*}$ & $-4.102^{*}$ & $-4.126^{*}$ & -3.457 \\
Cote d'Ivoire & -2.550 & -1.948 & -1.238 & -1.420 \\
Cameroon & $-5.255^{* *}$ & $-3.653^{*}$ & $-3.661^{*}$ & -2.788 \\
Congo, Rep. & -2.004 & -1.014 & -1.085 & -1.708 \\
Egypt & -1.426 & -1.512 & -2.043 & -2.013 \\
Ghana & -1.329 & -1.716 & -1.573 & -1.797 \\
Kenya & -3.149 & -2.891 & -3.356 & -3.170 \\
Morocco & -1.878 & -1.974 & -1.576 & -1.649 \\
Nigeria & $-4.039^{*}$ & -3.388 & -2.763 & -2.462 \\
Sudan & $-3.975^{*}$ & -3.037 & -2.582 & -2.059 \\
Tunisia & -3.043 & -1.979 & -2.180 & -1.879 \\
Zambia & $-4.669^{* *}$ & -2.968 & -1.994 & -1.691
\end{tabular}

Panel F: Catch-up rate for upper middle-income economies

\begin{tabular}{llccc} 
Algeria & -2.741 & -2.362 & -2.173 & -2.073 \\
Botswana & -1.255 & -1.074 & -0.712 & -0.287 \\
Gabon & -0.461 & -0.150 & 0.324 & 0.629 \\
Libya & $-4.049 *$ & -3.375 & -3.044 & -3.277 \\
Mauritius & -1.485 & -1.551 & -1.008 & -1.361 \\
South Africa & -3.487 & -3.189 & -2.045 & -2.320 \\
\hline
\end{tabular}

Notes: The test is performed under the assumption that there is an intercept and linear trend in the series (Case 3 in Pesaran, 2007). For the low income economies and upper middle-income economies, the $10 \%, 5 \%$ and $1 \%$ critical values for Case 3 with $T=50, N=10$ from Pesaran (2007) are -4.02 , 4.91 and -7.69 , respectively. For the lower middle-income economies, the $10 \%, 5 \%$ and $1 \%$ critical values for Case 3 with $T=50, N=15$ from Pesaran (2007) are $-3.63,-4.17$ and -5.48 , respectively. *, ** denote statistical significance at the $10 \%$ and $5 \%$ level, respectively. 
Table 9: Results for the individual African countries from panel KPSS test with multiple breaks

\begin{tabular}{|c|c|c|c|c|c|c|c|}
\hline \multirow[t]{2}{*}{ Economies } & \multirow{2}{*}{$\begin{array}{l}\text { KPSS test statistic } \\
\text { (using Bartlett kernel) }\end{array}$} & \multicolumn{6}{|c|}{ Break dates } \\
\hline & & $\mathrm{mi}$ & $T B_{1}$ & $T B_{2}$ & $T B_{3}$ & $T B_{4}$ & $T B_{5}$ \\
\hline \multicolumn{8}{|c|}{ Panel A: Low income economies } \\
\hline Benin & $0.248 * * *$ & 4 & 1985 & 1995 & 1999 & 2005 & - \\
\hline Congo, Dem. Rep. & $0.037 *$ & 3 & 1982 & 1998 & 2009 & - & - \\
\hline Ethiopia & 0.025 & 4 & 1982 & 1992 & 1999 & 2008 & - \\
\hline Mozambique & 0.078 & 2 & 1999 & 2003 & - & - & - \\
\hline Senegal & $0.315 * * *$ & 4 & 1979 & 1994 & 2002 & 2008 & - \\
\hline Togo & $0.030 * *$ & 5 & 1976 & 1982 & 1993 & 1998 & 2008 \\
\hline Tanzania & 0.033 & 5 & 1980 & 1986 & 1996 & 2003 & 2008 \\
\hline Zimbabwe & $0.139 * * *$ & 5 & 1984 & 1992 & 1998 & 2004 & 2008 \\
\hline \multicolumn{8}{|c|}{ Panel B: Lower middle-income economies } \\
\hline Angola & $0.131 * * *$ & 5 & 1975 & 1981 & 1994 & 2004 & 2008 \\
\hline Cote d'Ivoire & $0.039 *$ & 5 & 1978 & 1982 & 1998 & 2003 & 2008 \\
\hline Cameroon & $0.073 * * *$ & 3 & 1981 & 2003 & 2008 & - & - \\
\hline Congo, Rep. & 0.033 & 4 & 1982 & 1990 & 2000 & 2006 & - \\
\hline Egypt & $0.101 * * *$ & 4 & 1974 & 1983 & 2004 & 2008 & - \\
\hline Ghana & 0.027 & 5 & 1982 & 1987 & 1999 & 2004 & 2008 \\
\hline Kenya & 0.042 & 3 & 1985 & 2001 & 2008 & - & - \\
\hline Morocco & $0.054 * * *$ & 4 & 1979 & 1987 & 1993 & 2003 & - \\
\hline Nigeria & 0.028 & 5 & 1981 & 1986 & 1993 & 1997 & 2003 \\
\hline Sudan & $0.068 * * *$ & 3 & 1979 & 1993 & 2003 & - & - \\
\hline Tunisia & $0.045 * *$ & 3 & 1981 & 1985 & 1999 & - & - \\
\hline Zambia & $0.108 * * *$ & 1 & 1977 & - & - & - & - \\
\hline
\end{tabular}

Continued on next page 
Table 9 - Continued from previous page

\begin{tabular}{lccccccc}
\hline Panel C: Upper middle-income economies & $0.131^{* * *}$ & 3 & 1983 & 1993 & 2010 & - & - \\
Algeria & $0.118^{* * *}$ & 4 & 1987 & 1991 & 1997 & 2010 & - \\
Botswana & 0.045 & 3 & 1990 & 2001 & 2010 & - & - \\
Gabon & $0.092^{* * *}$ & 5 & 1984 & 1993 & 2001 & 2006 & 2010 \\
Libya & $0.638^{* * *}$ & 4 & 1983 & 1989 & 1999 & 2010 & - \\
Mauritius & $0.083^{* * *}$ & 3 & 1988 & 2007 & 2010 & - & - \\
South Africa & & & & & & & \\
& & & & & & & \\
Panel D: Catch-up rate for low income economies & & & & & \\
Benin & 0.023 & 4 & 1980 & 1995 & 1999 & 2003 & - \\
Congo, Dem. Rep. & 0.032 & 4 & 1980 & 1992 & 2002 & 2009 & - \\
Ethiopia & $0.151^{* * *}$ & 5 & 1974 & 1979 & 1994 & 2001 & 2005 \\
Mozambique & $0.321^{* * *}$ & 5 & 1974 & 1979 & 1994 & 2001 & 2005 \\
Senegal & $0.083 * * *$ & 4 & 1979 & 1996 & 2002 & 2008 & - \\
Togo & $0.085 * * *$ & 5 & 1978 & 1993 & 1998 & 2003 & 2008 \\
Tanzania & $0.200^{* * *}$ & 4 & 1979 & 1997 & 2001 & 2006 & - \\
Zimbabwe & $0.054 * * *$ & 5 & 1976 & 1990 & 1997 & 2002 & 2009 \\
& & & & & & & \\
Panel E: Catch-up rate for lower middle-income economies & & & & & \\
Angola & 0.029 & 5 & 1974 & 1990 & 1994 & 2001 & 2005 \\
Cote d'Ivoire & $0.095 * * *$ & 4 & 1982 & 1998 & 2003 & 2008 & - \\
Cameroon & $0.065 * * *$ & 4 & 1980 & 1994 & 2001 & 2006 & - \\
Congo, Rep. & $0.039 * * *$ & 3 & 1980 & 1993 & 2008 & - & - \\
Egypt & $0.071 * * *$ & 5 & 1977 & 1983 & 1993 & 2002 & 2009 \\
Ghana & $0.049 * * *$ & 4 & 1977 & 1985 & 1999 & 2006 & - \\
Kenya & $0.034 * *$ & 4 & 1979 & 1993 & 2000 & 2005 & - \\
Morocco & $0.054 * * *$ & 3 & 1974 & 1983 & 2002 & - & - \\
\hline Continued on next page & & & & & & & -
\end{tabular}

Continued on next page 
Table 9 - Continued from previous page

\begin{tabular}{|c|c|c|c|c|c|c|c|}
\hline Nigeria & $0.194 * * *$ & 5 & 1980 & 1990 & 1994 & 2001 & 2006 \\
\hline Sudan & $0.049 * * *$ & 4 & 1979 & 1992 & 2002 & 2009 & - \\
\hline Tunisia & 0.030 & 4 & 1985 & 1994 & 2000 & 2004 & - \\
\hline Zambia & $0.150 * * *$ & 5 & 1974 & 1979 & 1994 & 2001 & 2006 \\
\hline \multicolumn{8}{|c|}{ Panel F: Catch-up rate for upper middle-income economies } \\
\hline Algeria & $0.088 * * *$ & 3 & 1983 & 1993 & 2003 & - & - \\
\hline Botswana & 0.030 & 5 & 1987 & 1991 & 1997 & 2002 & 2010 \\
\hline Gabon & $0.048^{* * *}$ & 3 & 1989 & 1993 & 2010 & - & - \\
\hline Libya & $0.040 * * *$ & 5 & 1984 & 1993 & 2001 & 2006 & 2010 \\
\hline Mauritius & $0.147 * * *$ & 5 & 1985 & 1990 & 1996 & 2000 & 2003 \\
\hline South Africa & 0.04 & 4 & 1988 & 1991 & 2000 & 2007 & - \\
\hline
\end{tabular}

Notes: All results are generated by a model with an intercept and trend. The maximum number of breaks $\left(m_{i}\right)$ allowed is 5 . $*, * *, * * *$ denoted statistical significance at the $10 \%, 5 \%$ and $1 \%$ level, respectively. 
Table 10: Perron and Yabu (2009) and Kejriwal and Perron (2010) tests results

\begin{tabular}{|c|c|c|c|c|c|}
\hline \multirow[t]{2}{*}{ Economies } & \multirow[t]{2}{*}{ Model } & \multirow{2}{*}{$\begin{array}{c}\text { ExpW(1|0) } \\
\text { Test } \\
\end{array}$} & \multicolumn{3}{|c|}{$\operatorname{ExpW}(2 \mid 1)$} \\
\hline & & & Break date & Test & Break date \\
\hline \multicolumn{6}{|c|}{ Panel A: Low income economies } \\
\hline Benin & III & $11.906^{* *}$ & 1999 & $3.762 * *$ & 1977 \\
\hline Congo, Dem. Rep. & III & 2.255 & - & - & - \\
\hline Ethiopia & III & $4.927 * *$ & 1993 & $22.574 * * *$ & 1984 \\
\hline Mozambique & III & $24.257 * * *$ & 1999 & 1.973 & - \\
\hline Senegal & III & $6.969 * * *$ & 1987 & $5.048 * * *$ & 1992 \\
\hline Togo & III & $8.154 * * *$ & 1993 & 1.739 & - \\
\hline Tanzania & III & $9.132 * * *$ & 1999 & $3.493 * *$ & 1992 \\
\hline Zimbabwe & III & 1.805 & - & - & - \\
\hline \multicolumn{6}{|c|}{ Panel B: Lower middle-income economies } \\
\hline Angola & III & 2.519 & - & - & - \\
\hline Cote d'Ivoire & III & $14.710^{* * *}$ & 1990 & $5.499 * * *$ & 1981 \\
\hline Cameroon & III & $13.997 * * *$ & 2001 & $8.580^{* * *}$ & 1975 \\
\hline Congo, Rep. & III & $4.471 * *$ & 1998 & $5.577 * * *$ & 1983 \\
\hline Egypt & III & $3.671 * *$ & 1983 & 0.776 & - \\
\hline Ghana & III & $6.942 * * *$ & 2000 & $6.454 * * *$ & 1982 \\
\hline Kenya & III & $2.948^{*}$ & 1985 & $6.237 * * *$ & 1982 \\
\hline Morocco & III & 2.472 & - & - & - \\
\hline Nigeria & III & $3.320 * *$ & 1993 & $4.350 * *$ & 1977 \\
\hline Sudan & III & $6.774 * * *$ & 1993 & $3.112 *$ & 1979 \\
\hline Tunisia & III & $4.348^{* *}$ & 1981 & 1.091 & - \\
\hline Zambia & III & 1.462 & - & - & - \\
\hline \multicolumn{6}{|c|}{ Panel C: Upper middle-income economies } \\
\hline Algeria & III & $3.120 *$ & 1993 & 1.392 & - \\
\hline Botswana & III & 1.408 & - & - & - \\
\hline Gabon & III & $2.762^{*}$ & 2001 & $8.761 * * *$ & 1987 \\
\hline Libya & III & $24.308^{* * *}$ & 2002 & 1.457 & - \\
\hline Mauritius & III & $2.859^{*}$ & 1991 & $9.551 * * *$ & 1989 \\
\hline South Africa & III & $5.146 * * *$ & 1991 & $3.437 * *$ & 2000 \\
\hline \multicolumn{6}{|c|}{ Panel D: Catch-up rate for low income economies } \\
\hline Benin & III & $11.406^{* * *}$ & 1985 & 2.106 & - \\
\hline Congo, Dem. Rep. & III & 0.712 & - & - & - \\
\hline Ethiopia & III & $10.733 * * *$ & 2002 & 1.703 & - \\
\hline Mozambique & III & 1.150 & - & - & - \\
\hline Senegal & III & $3.262 * *$ & 1997 & 0.973 & - \\
\hline Togo & III & $4.955^{* * *}$ & 1997 & 2.088 & - \\
\hline Tanzania & III & 1.695 & - & - & - \\
\hline Zimbabwe & III & $2.868^{*}$ & 2002 & 1.194 & - \\
\hline
\end{tabular}


Table 10 - Continued from previous page

Panel E: Catch-up rate for lower middle-income economies

$\begin{array}{lccccc}\text { Angola } & \text { III } & 1.561 & - & - & - \\ \text { Cote d'Ivoire } & \text { III } & 3.702^{* *} & 1996 & 1.194 & - \\ \text { Cameroon } & \text { III } & 9.257^{* * *} & 2002 & 1.066 & - \\ \text { Congo, Rep. } & \text { III } & 3.969^{* *} & 2006 & 1.562 & - \\ \text { Egypt } & \text { III } & 4.867 * * * & 1988 & 1.015 & - \\ \text { Ghana } & \text { III } & 7.205^{* * *} & 2002 & 3.145^{*} & 1997 \\ \text { Kenya } & \text { III } & 6.161^{* * *} & 2002 & 0.696 & - \\ \text { Morocco } & \text { III } & 30.466^{* * *} & 2002 & 0.967 & - \\ \text { Nigeria } & \text { III } & 4.552^{* *} & 2002 & 1.658 & - \\ \text { Sudan } & \text { III } & 4.132^{* *} & 2003 & 1.368 & - \\ \text { Tunisia } & \text { III } & 5.560^{* * *} & 2002 & 1.058 & - \\ \text { Zambia } & \text { III } & 1.318 & - & - & - \\ & & & & & \\ \text { Panel F: Catch-up rate for } & \text { upper middle-income economies } & & \\ \text { Algeria } & \text { III } & 5.194 * * * & 2003 & 2.963 * & 1993 \\ \text { Botswana } & \text { III } & 5.302^{* * *} & 2002 & 1.008 & - \\ \text { Gabon } & \text { III } & 1.867 & - & - & - \\ \text { Libya } & \text { III } & 21.156^{* * *} & 2003 & 4.805 * * & 1995 \\ \text { Mauritius } & \text { III } & 5.122^{* * *} & 2002 & 1.811 & - \\ \text { South Africa } & \text { III } & 1.881 & - & - & -\end{array}$

Notes: Model III refers to structural change in both intercept and slope. We follow a sequential procedure that first test the null of on breaks against one break. For the countries that the null is rejected, we test the null of one break against two breaks. The Gauss codes for these tests are available from Pierre Perron's website at: http://people.bu.edu/perron/code/breakcode.zip. *,**,*** denoted statistical significance at the $10 \%, 5 \%$ and $1 \%$ level, respectively. 
Table 11: Results for RALS-LM unit root tests with no breaks, one break or two breaks

\begin{tabular}{|c|c|c|c|c|c|}
\hline \multirow{2}{*}{ Economies } & \multicolumn{2}{|l|}{ RALS-LM } & \multirow{2}{*}{$\widehat{T}_{B}$} & & \multirow{2}{*}{$\hat{k}$} \\
\hline & $\tau_{R A L S-L M}^{*}$ & $\hat{\rho}^{2}$ & & & \\
\hline \multicolumn{6}{|c|}{ Panel A: Low income economies } \\
\hline Benin & $-4.338 * *$ & 0.874 & 1996 & 2004 & 3 \\
\hline Congo, Dem. Rep. & 0.441 & 0.459 & - & - & 0 \\
\hline Ethiopia & $-3.760 * *$ & 0.521 & 1983 & 2007 & 0 \\
\hline Mozambique & $-5.818^{* * *}$ & 0.641 & 1998 & - & 8 \\
\hline Senegal & -2.328 & 0.698 & 1983 & 1994 & 6 \\
\hline Togo & $-3.576^{* *}$ & 0.751 & 1994 & - & 1 \\
\hline Tanzania & $-4.514 * *$ & 0.910 & 1996 & 2004 & 0 \\
\hline Zimbabwe & $-4.499 * * *$ & 0.584 & - & - & 7 \\
\hline
\end{tabular}

Panel B: Lower middle-income economies

$\begin{array}{lccccc}\text { Angola } & -2.974 * & 0.895 & - & - & 3 \\ \text { Cote d'Ivoire } & -6.236 * * & 0.758 & 2002 & 2006 & 3 \\ \text { Cameroon } & -5.341 * * * & 0.995 & 1997 & 2002 & 5 \\ \text { Congo, Rep. } & -5.413 * * * & 0.909 & 2004 & 2007 & 0 \\ \text { Egypt } & -1.692 & 0.906 & 2008 & - & 0 \\ \text { Ghana } & -6.201 * * * & 0.171 & 1982 & 1998 & 8 \\ \text { Kenya } & -4.760 * * * & 0.989 & 1991 & 2002 & 8 \\ \text { Morocco } & -2.782 * & 0.923 & - & - & 7 \\ \text { Nigeria } & -5.865 * * * & 0.761 & 1992 & 2002 & 5 \\ \text { Sudan } & -5.756 * * * & 0.720 & 1992 & 2005 & 8 \\ \text { Tunisia } & -3.825 * * & 0.844 & 2007 & - & 0 \\ \text { Zambia } & -3.631 * * * & 0.814 & - & - & 0\end{array}$

Panel C: Upper middle-income economies

$\begin{array}{lccccc}\text { Algeria } & -4.724 * * * & 0.645 & 2001 & - & 4 \\ \text { Botswana } & -0.545 & 0.520 & - & - & 7 \\ \text { Gabon } & -3.846 * * & 0.667 & 1996 & 2010 & 7 \\ \text { Libya } & -6.233 * * * & 0.713 & 1993 & - & 0 \\ \text { Mauritius } & -12.843 * * * & 0.295 & 1998 & 2009 & 5 \\ \text { South Africa } & -5.151 * * * & 0.866 & 1992 & 1998 & 1\end{array}$

Panel D: Catch-up rate for low income economies

\begin{tabular}{lccccc} 
Benin & $-4.726^{* * *}$ & 0.702 & 1998 & - & 5 \\
Congo, Dem. Rep. & -0.215 & 0.737 & - & - & 1 \\
Ethiopia & -3.062 & 0.988 & 2001 & - & 1 \\
Mozambique & -2.112 & 0.989 & - & - & 1 \\
Senegal & $-6.142^{* * *}$ & 0.590 & 2007 & - & 3 \\
Togo & -2.932 & 0.611 & 2001 & - & 5 \\
Tanzania & -1.868 & 0.975 & - & - & 1 \\
Zimbabwe & $-4.465^{* * *}$ & 0.725 & 2001 & - & 7 \\
\hline
\end{tabular}

Continued on next page 
Table 11 - Continued from previous page

Panel E: Catch-up rate for lower middle-income economies

$\begin{array}{lccccc}\text { Angola } & -2.759 * & 0.706 & - & - & 2 \\ \text { Cote d'Ivoire } & -3.852 * * * & 0.415 & 2007 & - & 5 \\ \text { Cameroon } & -2.627 & 0.778 & 2000 & - & 1 \\ \text { Congo, Rep. } & -1.747 & 0.918 & 2008 & - & 1 \\ \text { Egypt } & -4.686^{* * *} & 0.971 & 1998 & - & 7 \\ \text { Ghana } & -6.885 * * * & 0.419 & 1982 & 1998 & 5 \\ \text { Kenya } & -3.368 & 0.956 & 2001 & - & 5 \\ \text { Morocco } & -3.464 * & 0.926 & 2001 & - & 0 \\ \text { Nigeria } & -3.882 * * & 0.958 & 2004 & - & 7 \\ \text { Sudan } & -3.289 & 0.871 & 2002 & - & 3 \\ \text { Tunisia } & -2.400 & 0.918 & 2000 & - & 2 \\ \text { Zambia } & -1.816 & 0.875 & - & - & 0\end{array}$

Panel F: Catch-up rate for upper middle-income economies

\begin{tabular}{lccccc} 
Algeria & $-3.975^{* * *}$ & 0.188 & 1990 & 2000 & 6 \\
Botswana & -2.881 & 0.592 & 1998 & - & 1 \\
Gabon & -1.295 & 0.367 & - & - & 2 \\
Libya & $-14.193 * * *$ & 0.320 & 1992 & 1999 & 8 \\
Mauritius & $-3.694 * *$ & 0.967 & 1998 & - & 8 \\
South Africa & -1.881 & 0.891 & - & - & 2 \\
\hline
\end{tabular}

Notes: The term $\widehat{T}_{B}$ stands for the locations of the structural breaks, $\hat{k}$ represents the optimal lag length decided by a general to specific procedure. Test statistic for the RALS-LM unit root tests are invariant to the break locations. Critical values for the tests are provided in Meng et al. (2014) or can be calculated using the critical values calculator RATS code from Junsoo Lee's homepage at: https://sites.google.com/site/junsoolee/codes. $* * *, * * *$ denoted statistical significance at the $10 \%, 5 \%$ and $1 \%$ level, respectively. 
Figure 1: Energy consumption per capita in different economies relative to the mean energy use (1981-2013)
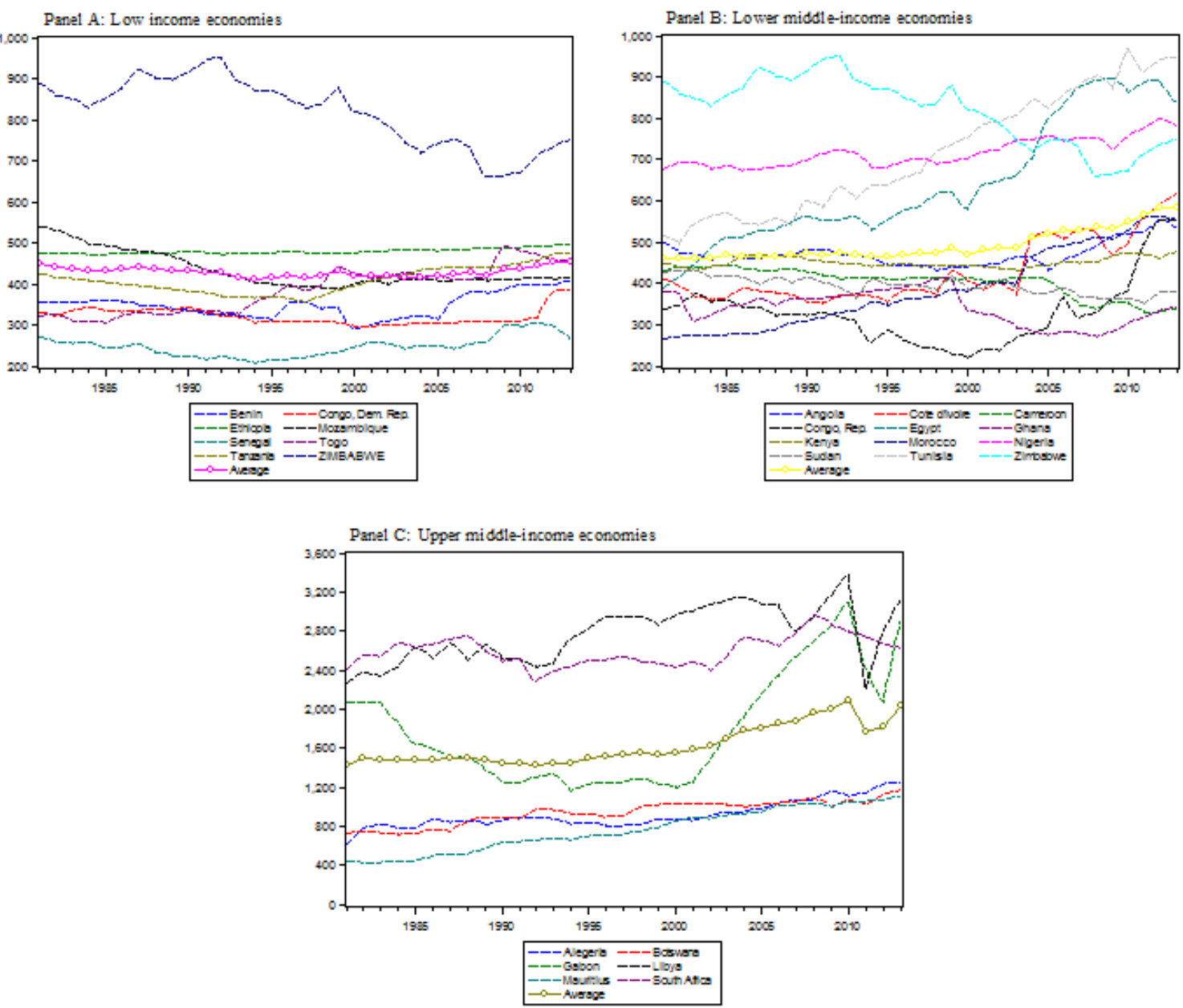
Figure 2: Catch-up rate in African economies (1981-2013)
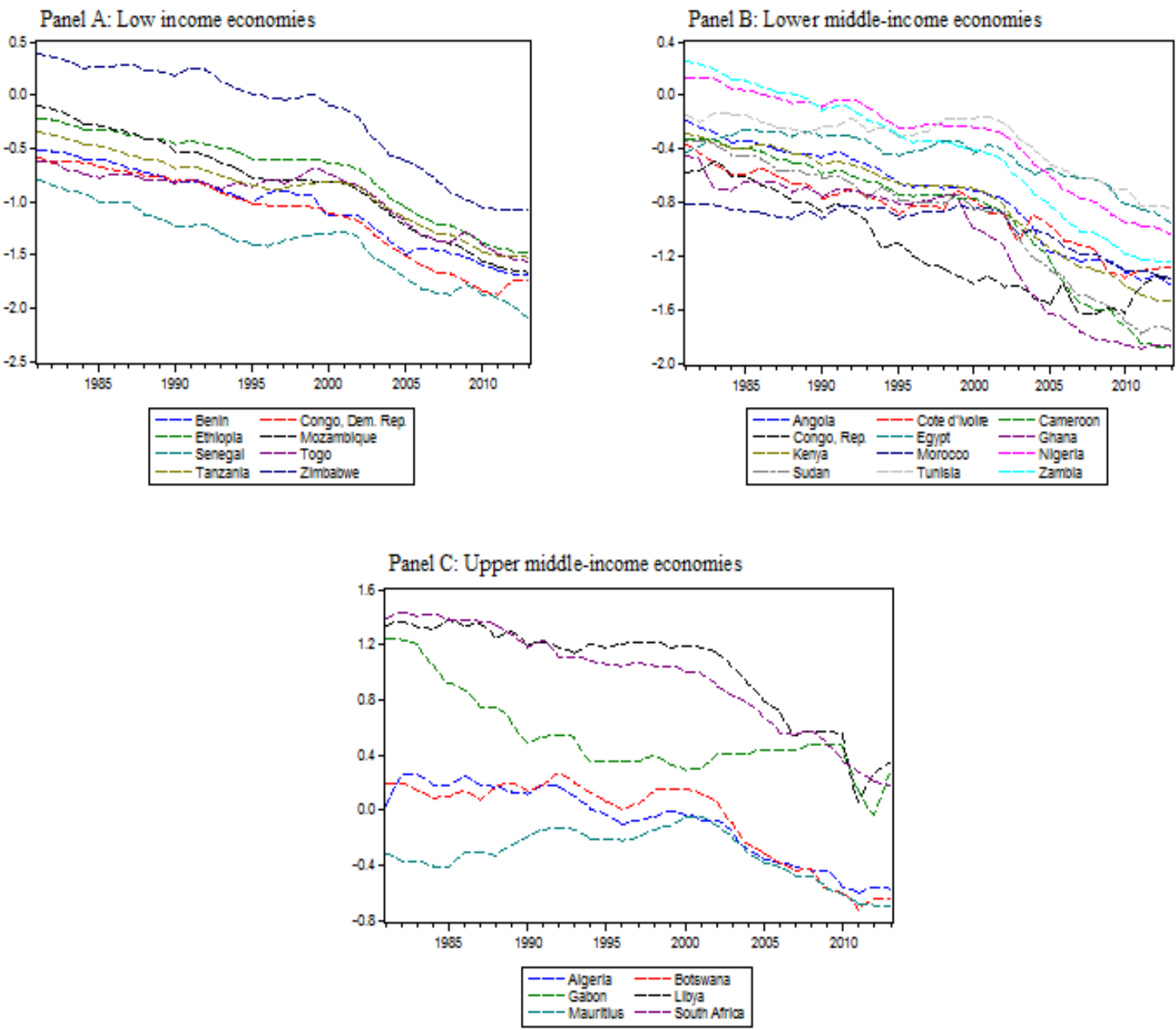
Figure 3: Growth rate of catch-up in African economies (1982-2013)
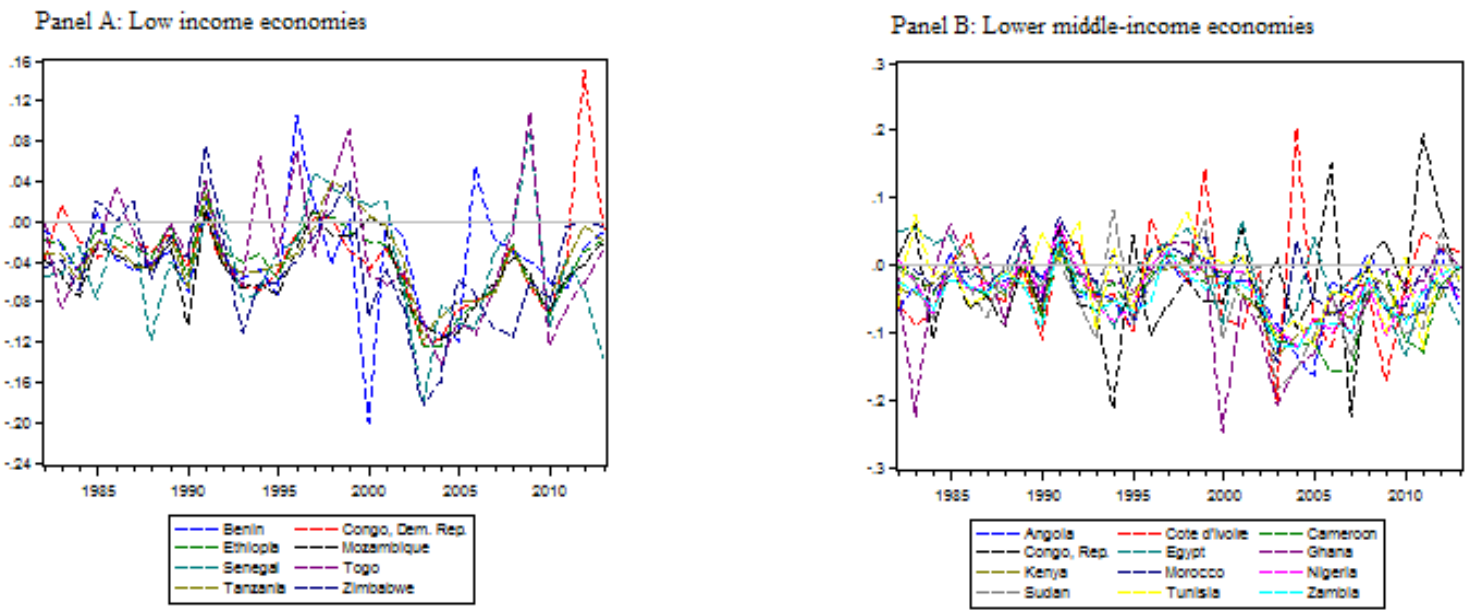

Panel C: Upper middle-income economies

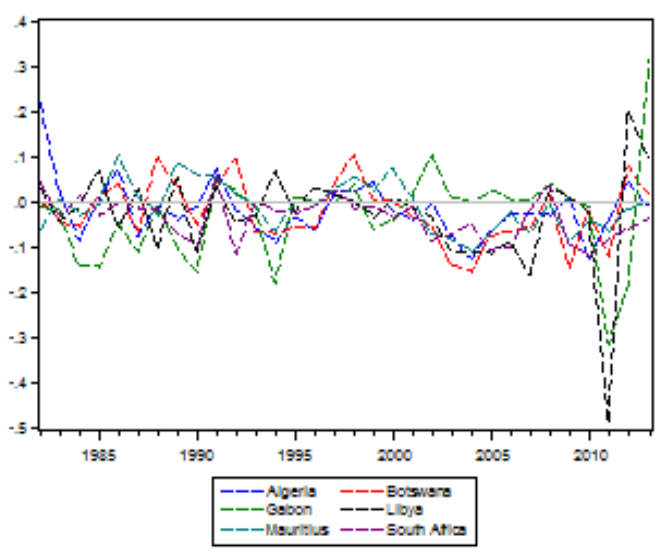




\section{Appendix}

Table A1: Conventional panel unit root tests results

\begin{tabular}{lcc}
\hline Economies & LLC & Hadri Z \\
\hline Panel A: Energy consumption per capita & & \\
Low income economies & 1.039 & $7.331^{* * *}$ \\
Lower middle-income economies & 0.197 & $8.542^{* * *}$ \\
Upper middle-income economies & -0.943 & $7.145^{* * *}$ \\
& & \\
Panel B: Catch-up rate & & \\
Low income economies & 18.235 & $6.039^{* * *}$ \\
Lower middle-income economies & 15.263 & $9.624^{* * *}$ \\
Upper middle-income economies & 6.958 & $7.475^{* * *}$ \\
\hline
\end{tabular}

Notes: The test statistics for the two panel unit root tests are LLC adjusted t statistic and Hadri Z statistic respectively. The maximum lag length chosen for LLC test is 12 . Both tests are generated by a model with time and trend. Two tests use the automatic bandwidth selection technique of Newey-West and Bartlett Kernel for computing the spectrum. *** denotes statistical significance at the $1 \%$ level.

Table A1 presents the results of Levin et al. (2002) and Hadri (2000) panel unit root tests, where the former has the null hypothesis that panels contain unit roots while the latter with the null that all panels are stationary. We apply two panel stationarity tests with opposite null because jointly testing of both null hypotheses can ascertain stationarity results. Table A1 shows that the LLC test statistic cannot reject the null hypothesis for all panels, which indicates that that the per capita energy consumption for the three economies in Africa does not converge to its mean value. The Hadri $\mathrm{Z}$ statistic rejects the null hypothesis of stationarity at the $1 \%$ level which confirms the divergence finding of energy consumption per capita. Similarly, both test statistics provide strong evidence of divergence in catch-up rate for the three economies.

The results of conventional time series unit root tests for per capita energy consumption and its catch-up rate are provided in Table A2. As evident in Table A2, the results for the ADF and PP tests suggest that the null hypothesis of unit root cannot be rejected in any African counties except for Zambia. In the KPSS test, the null of stationarity is rejected for 22 out of 26 series. Therefore, we conclude that 5 countries are converging towards the average per capita energy consumption of their belonged economies. In terms of the catch-up rate, both $\mathrm{ADF}$ and PP test statistics show that the null hypothesis cannot be rejected in all the African countries. Yet, the result for KPSS test indicates the null hypothesis that the series under consideration does not contain a unit root is rejected among 21 countries. On the basis of the traditional time series stationarity test, it can be concluded that the catch-up rates of 5 countries stochastically converge around the level of China during 1971-2014. 
Table A2: Traditional time series unit root tests results

\begin{tabular}{|c|c|c|c|c|c|c|}
\hline \multirow[t]{2}{*}{ Economies } & \multicolumn{6}{|c|}{ Test Statistic } \\
\hline & ADF & Lag length & $\mathrm{PP}$ & Bandwidth & KPSS & Bandwidth \\
\hline \multicolumn{7}{|c|}{ Panel A: Low income economies } \\
\hline Benin & -1.699 & 0 & -1.851 & 1 & $0.134 *$ & 4 \\
\hline Congo, Dem. Rep. & -0.787 & 0 & -1.217 & 2 & $0.139 *$ & 4 \\
\hline Ethiopia & -2.225 & 0 & -2.201 & 2 & $0.205^{* *}$ & 5 \\
\hline Mozambique & -0.290 & 0 & -0.232 & 1 & $0.213^{* *}$ & 5 \\
\hline Senegal & -1.716 & 0 & -1.683 & 2 & $0.167^{* *}$ & 5 \\
\hline Togo & -2.661 & 0 & -2.675 & 6 & 0.100 & 4 \\
\hline Tanzania & -0.830 & 0 & -0.877 & 2 & $0.209 * *$ & 5 \\
\hline Zimbabwe & -1.753 & 1 & -1.481 & 2 & $0.185^{* *}$ & 5 \\
\hline \multicolumn{7}{|c|}{ Panel B: Lower middle-income economies } \\
\hline Angola & -1.711 & 0 & -1.589 & 3 & $0.196^{* *}$ & 4 \\
\hline Cote d'Ivoire & -1.673 & 0 & -1.547 & 1 & $0.213^{* *}$ & 5 \\
\hline Cameroon & -0.964 & 0 & -0.973 & 7 & $0.197^{* *}$ & 5 \\
\hline Congo, Rep. & -0.343 & 0 & -0.248 & 4 & $0.157^{* *}$ & 5 \\
\hline Egypt & -0.522 & 0 & -0.560 & 1 & $0.183^{* *}$ & 5 \\
\hline Ghana & -1.773 & 0 & -1.980 & 3 & $0.128^{*}$ & 5 \\
\hline Kenya & -2.563 & 0 & -2.517 & 4 & $0.146^{* *}$ & 4 \\
\hline Morocco & -2.681 & 0 & -2.679 & 2 & 0.075 & 4 \\
\hline Nigeria & -1.150 & 0 & -0.806 & 5 & $0.204 * *$ & 5 \\
\hline Sudan & -3.120 & 0 & -3.062 & 3 & 0.102 & 5 \\
\hline Tunisia & -1.330 & 1 & -1.692 & 4 & $0.171 * *$ & 5 \\
\hline Zambia & $-4.272 * * *$ & 0 & $-4.441 * * *$ & 3 & $0.129^{*}$ & 3 \\
\hline \multicolumn{7}{|c|}{ Panel C: Upper middle-income economies } \\
\hline Algeria & -2.083 & 0 & -2.088 & 2 & $0.183^{* *}$ & 5 \\
\hline Botswana & -1.698 & 0 & -1.698 & 0 & $0.154^{* *}$ & 4 \\
\hline Gabon & -0.941 & 0 & -0.941 & 0 & $0.201^{* *}$ & 5 \\
\hline Libya & -2.478 & 0 & -2.478 & 0 & $0.211 * *$ & 5 \\
\hline Mauritius & -2.579 & 0 & -2.613 & 2 & 0.108 & 5 \\
\hline South Africa & -1.602 & 4 & -3.091 & 3 & $0.172 * *$ & 4 \\
\hline \multicolumn{7}{|c|}{ Panel D: Catch-up rate for low-income economies } \\
\hline Benin & -2.268 & 0 & -2.359 & 1 & $0.171^{* *}$ & 4 \\
\hline Congo, Dem. Rep. & -1.954 & 1 & -1.770 & 3 & $0.174^{* *}$ & 5 \\
\hline Ethiopia & -1.430 & 1 & -0.982 & 3 & $0.183^{* *}$ & 5 \\
\hline Mozambique & -2.652 & 1 & -2.817 & 3 & 0.102 & 5 \\
\hline Senegal & -2.758 & 1 & -2.337 & 2 & 0.085 & 4 \\
\hline Togo & -0.899 & 0 & -1.272 & 3 & $0.138^{*}$ & 5 \\
\hline Tanzania & -2.612 & 1 & -2.151 & 3 & 0.093 & 5 \\
\hline Zimbabwe & -1.438 & 1 & -1.130 & 2 & $0.173 * *$ & 5 \\
\hline
\end{tabular}

Continued on next page 
Table A2 - Continued from previous page

Panel E: Catch-up rate for lower middle-income economies

$\begin{array}{lcccccc}\text { Angola } & -1.768 & 0 & -1.768 & 0 & 0.135^{*} & 5 \\ \text { Cote d'Ivoire } & -3.140 & 0 & -3.083 & 2 & 0.113 & 4 \\ \text { Cameroon } & -1.473 & 1 & -0.878 & 3 & 0.192^{* *} & 5 \\ \text { Congo, Rep. } & -1.461 & 0 & -1.527 & 3 & 0.118 & 4 \\ \text { Egypt } & -0.277 & 0 & -0.117 & 4 & 0.211^{* *} & 5 \\ \text { Ghana } & -1.397 & 0 & -1.594 & 3 & 0.169^{* *} & 5 \\ \text { Kenya } & -1.857 & 1 & -1.405 & 2 & 0.183^{* *} & 5 \\ \text { Morocco } & -1.217 & 0 & -1.169 & 4 & 0.192^{* *} & 5 \\ \text { Nigeria } & -1.230 & 1 & -0.803 & 1 & 0.196^{* *} & 5 \\ \text { Sudan } & -1.212 & 0 & -1.476 & 4 & 0.159^{* *} & 5 \\ \text { Tunisia } & -0.963 & 0 & -0.963 & 0 & 0.193^{* *} & 5 \\ \text { Zambia } & -1.468 & 1 & -1.728 & 3 & 0.171^{* *} & 5\end{array}$

Panel F: Catch-up rate for upper middle-income economies

$\begin{array}{lcccccc}\text { Algeria } & -2.426 & 0 & -2.403 & 2 & 0.203 * * & 5 \\ \text { Botswana } & -1.677 & 1 & -1.516 & 1 & 0.178^{* *} & 4 \\ \text { Gabon } & -2.102 & 0 & -1.998 & 3 & 0.167 * * & 5 \\ \text { Libya } & -2.272 & 0 & -2.320 & 3 & 0.210^{* *} & 5 \\ \text { Mauritius } & -1.271 & 1 & -1.160 & 4 & 0.136^{*} & 5 \\ \text { South Africa } & -0.846 & 0 & -0.846 & 0 & 0.203 * * & 5\end{array}$

Notes: The lag length for ADF test is decided by using Schwartz Information Criterion (SIC). For PP and KPSS tests, the optimal bandwidth is selected by Newey-West method using Bartlett kernel. All stationarity tests are performed under the assumption of constant term and linear trend in the series. The maximum length selected in all cases is $9 . *, * *, * * *$ denote statistical significance at the $10 \%, 5 \%$ and $1 \%$ level, respectively. 
Table A3: Critical values for the panel KPSS test with multiple breaks

\begin{tabular}{|c|c|c|c|c|}
\hline Critical values & $10 \%$ & $5 \%$ & $2.5 \%$ & $1 \%$ \\
\hline \multicolumn{5}{|c|}{ Panel A: Low income economies } \\
\hline Benin & 0.023 & 0.025 & 0.027 & 0.029 \\
\hline Congo, Dem. Rep. & 0.032 & 0.038 & 0.044 & 0.051 \\
\hline Ethiopia & 0.045 & 0.055 & 0.063 & 0.072 \\
\hline Mozambique & 0.081 & 0.104 & 0.124 & 0.161 \\
\hline Senegal & 0.034 & 0.041 & 0.048 & 0.057 \\
\hline Togo & 0.024 & 0.027 & 0.029 & 0.031 \\
\hline Tanzania & 0.035 & 0.042 & 0.047 & 0.056 \\
\hline Zimbabwe & 0.055 & 0.071 & 0.086 & 0.103 \\
\hline
\end{tabular}

Panel B: Lower middle-income economies

$\begin{array}{lllll}\text { Angola } & 0.026 & 0.029 & 0.031 & 0.034 \\ \text { Cote d'Ivoire } & 0.035 & 0.040 & 0.045 & 0.051 \\ \text { Cameroon } & 0.022 & 0.024 & 0.025 & 0.027 \\ \text { Congo, Rep. } & 0.044 & 0.054 & 0.063 & 0.076 \\ \text { Egypt } & 0.039 & 0.045 & 0.054 & 0.062 \\ \text { Ghana } & 0.048 & 0.058 & 0.067 & 0.080 \\ \text { Kenya } & 0.061 & 0.076 & 0.091 & 0.115 \\ \text { Morocco } & 0.032 & 0.038 & 0.045 & 0.050 \\ \text { Nigeria } & 0.040 & 0.049 & 0.056 & 0.065 \\ \text { Sudan } & 0.031 & 0.036 & 0.041 & 0.046 \\ \text { Tunisia } & 0.029 & 0.034 & 0.039 & 0.045 \\ \text { Zambia } & 0.025 & 0.028 & 0.031 & 0.034\end{array}$

Panel C: Upper middle-income economies

$\begin{array}{lllll}\text { Algeria } & 0.030 & 0.034 & 0.036 & 0.041 \\ \text { Botswana } & 0.034 & 0.039 & 0.045 & 0.055 \\ \text { Gabon } & 0.055 & 0.068 & 0.080 & 0.106 \\ \text { Libya } & 0.026 & 0.028 & 0.030 & 0.032 \\ \text { Mauritius } & 0.025 & 0.027 & 0.030 & 0.035 \\ \text { South Africa } & 0.043 & 0.051 & 0.057 & 0.069\end{array}$

Panel D: Catch-up rate for low-income economies

\begin{tabular}{lllll} 
Benin & 0.024 & 0.027 & 0.029 & 0.032 \\
Congo, Dem. Rep. & 0.038 & 0.045 & 0.050 & 0.063 \\
Ethiopia & 0.027 & 0.032 & 0.036 & 0.043 \\
Mozambique & 0.026 & 0.030 & 0.034 & 0.040 \\
Senegal & 0.040 & 0.047 & 0.052 & 0.062 \\
Togo & 0.033 & 0.038 & 0.042 & 0.048 \\
Tanzania & 0.043 & 0.049 & 0.054 & 0.062 \\
Zimbabwe & 0.027 & 0.030 & 0.034 & 0.037 \\
\hline
\end{tabular}


Table A3 - Continued from previous page

Panel E: Catch-up rate for lower middle-income economies

$\begin{array}{lllll}\text { Angola } & 0.029 & 0.034 & 0.038 & 0.043 \\ \text { Cote d'Ivoire } & 0.047 & 0.058 & 0.070 & 0.084 \\ \text { Cameroon } & 0.028 & 0.031 & 0.035 & 0.040 \\ \text { Congo, Rep. } & 0.024 & 0.027 & 0.030 & 0.036 \\ \text { Egypt } & 0.025 & 0.028 & 0.031 & 0.037 \\ \text { Ghana } & 0.026 & 0.029 & 0.032 & 0.036 \\ \text { Kenya } & 0.025 & 0.028 & 0.032 & 0.037 \\ \text { Morocco } & 0.022 & 0.024 & 0.026 & 0.030 \\ \text { Nigeria } & 0.034 & 0.041 & 0.049 & 0.058 \\ \text { Sudan } & 0.024 & 0.027 & 0.030 & 0.034 \\ \text { Tunisia } & 0.031 & 0.037 & 0.042 & 0.047 \\ \text { Zambia } & 0.026 & 0.029 & 0.033 & 0.040\end{array}$

Panel F: Catch-up rate for upper middle-income economies

$\begin{array}{lllll}\text { Algeria } & 0.021 & 0.023 & 0.024 & 0.026 \\ \text { Botswana } & 0.034 & 0.042 & 0.046 & 0.056 \\ \text { Gabon } & 0.025 & 0.027 & 0.030 & 0.032 \\ \text { Libya } & 0.026 & 0.029 & 0.031 & 0.034 \\ \text { Mauritius } & 0.029 & 0.032 & 0.035 & 0.039 \\ \text { South Africa } & 0.043 & 0.05 & 0.057 & 0.065\end{array}$

Notes: Bootstrap critical values are based on a Monte Carlo simulation with 2000 replications. 
Table A4: Major events in African countries around the break dates

\begin{tabular}{|c|c|c|}
\hline Economies & Break dates & Major events around the break dates \\
\hline \multicolumn{3}{|c|}{ Panel A: Low income economies } \\
\hline Benin & 1996, 1998, 2004 & $\begin{array}{l}\text { 1996: Mathieu Kerekou, former Benin dictator, was elected over incumbent Nicephore Soglo } \\
\text { 2000: The Cotonou Agreement }{ }^{1} \text {, a treaty between the European Union and the group of } \\
\text { African, Caribbean and Pacific States (ACP countries). The agreement ceased to be legal } \\
\text { under the WTO rules. } \\
\text { 2004: Eight French speaking African countries }{ }^{2} \text { began retiring over } 1 \text { billion in decaying } \\
\text { currency with new CFA francs. }\end{array}$ \\
\hline Congo, Dem. Rep. & - & \\
\hline Ethiopia & $1983,2001,2007$ & $\begin{array}{l}\text { 1985: Mahele Lieko Bokoungo fought back Congo's Laurent Kabila, who set up a rebel } \\
\text { republic on the shores of Lake Tanganyika near Moba. } \\
\text { 2000: Congo civil war } \\
\text { 2007: Fortunat Lumu, the head of Congo's atomic energy commission, was arrested along } \\
\text { with an aide of suspicion of illegally selling uranium. }\end{array}$ \\
\hline Mozambique & 1998 & $\begin{array}{l}\text { 1999: Creditors cancelled over } \$ 4 \text { billion worth of debt. The annual debt service of over } \$ 100 \\
\text { million had flowed to creditors in wealthy nations. }\end{array}$ \\
\hline Senegal & $1983,1994,2007$ & $\begin{array}{l}\text { 1983: Rebel fighters with the Movement of the Democratic Forces (MFDC) began a low level } \\
\text { insurgency against the government. } \\
\text { 1994: Gambian soldiers proclaimed military government in Dakar, Senegal. } \\
\text { 2007: The president Abdoulaye Wade, hosted the Islamic Development Bank's annual } \\
\text { meeting, and spoke on behalf of the bank to launch a } \$ 10 \text { billion fund to combat poverty in } \\
\text { developing Muslim countries in Africa and other parts of the world. }\end{array}$ \\
\hline Togo & 1994,2001 & $\begin{array}{l}\text { 1994: Legislative election were marked by army violence and intimidation. } \\
\text { 2000: } 36 \text { African heads of state signed a draft treaty which regarded as a step forward an } \\
\text { African Union. }\end{array}$ \\
\hline Tanzania & 1996, 2004 & 1997: The worst drought in 40 years happened in Tanzania. \\
\hline
\end{tabular}

\footnotetext{
${ }^{1}$ Cotonou is the largest city in Benin. The agreement was signed by 79 ACP nations and 15 members of EU. It is the latest agreement in the history of ACP-EU development cooperation.

2 They are Benin, Burkina Faso, Guinea-Bissau, Ivory Coast, Mali, Niger, Senegal and Togo.
} 
Table A4 - Continued from previous page

2002: The US government has forgiven all the remaining \$21.3 million debt owned by the Tanzania government.

Zimbabwe $2001 \quad$ 2000: After the IMF announced it would nor resume financial aids, the Zimbabwe stock exchange made a record of 500 points gain. Moreover, the official inflation was $53.6 \%$ and local cash cannot be moved out of the country.

Panel B: Lower middle-income economies

Angola

Cote d'Ivoire

$2002,2006,2007$

Caneroon

Cameroon

$1997,2000,2002$

Congo, Rep.

2004, 2007, 2008 2007: Congo and the London Club of private creditors reached a deal of cancelling $80 \%$ of the
Central African country's $\$ 2.5$ billion debt.

2008: Leaders of the six Central African states ${ }^{3}$, met to discuss closer economic ties. The Economic and Monetary Union of Central Africa (CEMAC), planned discussions on such issues as monetary reform and the free movement of citizens.
Egypt $\quad 1998,2008$
Ghana $\quad 1982,1998$
2011: Egyptians staged nationwide demonstrations against the President Mubarak. The parliament is dissolved and the constitution is suspended.
1981: The president Hilla Limann is ousted following two years of a weak government and stagnant economy.
2001: The government removed fuel subsidies which led to a $60 \%$ increase in petrol prices.

\begin{tabular}{ll} 
Kenya $1991,2001,2002$ & $1992:$ Ethnic violence erupted in western Kenya. \\
\hline Continued on next page &
\end{tabular}

\footnotetext{
${ }^{3}$ Specifically, they are Cameroon, Chad, Gabon, CAR, Congo, Rep. and Equatorial Guinea.
} 
Table A4 - Continued from previous page

\begin{tabular}{|c|c|c|}
\hline & & $\begin{array}{l}\text { 2001: The head of government Leaky charged with abuse of power and perverting the course } \\
\text { of justice. } \\
\text { 2002: Mwai Kibaki won landslide victory ending Moi's } 24 \text {-year long rule and } \mathrm{KANU}^{4} \text { 's four } \\
\text { decades in power. }\end{array}$ \\
\hline Morocco & 2001 & 1998: The first opposition-led government came into power. \\
\hline Nigeria & $1992,2002,2004$ & $\begin{array}{l}\text { 1992: Commercial creditors forgave most of Nigeria's debt. } \\
\text { 2002: Nigeria's parliament approved changes to an oil revenue-sharing law which gives state } \\
\text { governments a share of revenues from offshore oil and gas production. } \\
\text { 2004: The oil giant Royal Dutch/Shell declared it plans to streamline its operations in Nigeria. } \\
\text { An estimated } 30 \text { percent of its workforce will be laid off. }\end{array}$ \\
\hline Sudan & $1992,2002,2005$ & $\begin{array}{l}\text { 1991: UNICEF reported fighting and crop failures in southern Sudan had forced an unexpected } \\
\text { exodus of 200,000 people. } \\
\text { 2002: Sudan's government signed an agreement with rebels to suspend fighting to end their } \\
\text { 20-year war. } \\
\text { 2004: China invested nearly } \$ 150 \text { million in Sudan this year. }\end{array}$ \\
\hline Tunisia & 2000, 2007 & $\begin{array}{l}\text { 1999: Algeria, Libya and Tunisia agreed to share the northwest Sahara aquifer system. } \\
\text { 2007: Tunisia blocked access to the popular video sharing websites YouTube and } \\
\text { DailyMotion, which both contain materials about Tunisian political prisoners. }\end{array}$ \\
\hline Zambia & - & \\
\hline \multicolumn{3}{|c|}{ Panel C: Upper middle-income economies } \\
\hline Algeria & $1990,2000,2001$ & $\begin{array}{l}\text { 1991: Islamic Salvation Front (FIS) called general strike after ban placed on political } \\
\text { campaigning in mosques, state of emergency declared. } \\
\text { 1999: The president Bouteflika ordered release of } 5,000 \text { political and religious detainees } \\
\text { Berber protest in Kabylie region turned violent. }\end{array}$ \\
\hline Botswana & 1998 & $\begin{array}{l}\text { 1997: Constitutional amendment approved that presidency limited to two five-year terms and } \\
\text { voting age lowered to } 18 \text { from } 21 \text {. } \\
\text { 2001: According to UNAIDS, Botswana was reported to have the world's highest HIV } \\
\text { infection rate at } 38.3 \% \text { of the population. }\end{array}$ \\
\hline
\end{tabular}

Continued on next page ${ }^{4}$ KANU is the abbreviation of Kenya African National Union. It is a political party that ruled for almost 40 years after Kenya's independence from British colonial rule in
1963 until its electoral loss in 2002. 
Table A4 - Continued from previous page

\begin{tabular}{|c|c|c|}
\hline Gabon & 1996, 2010 & $\begin{array}{l}\text { 1993: The president Omar Bongo Ondimba declared that president following elections under } \\
\text { the multiparty system. } \\
\text { 2012: The Africa cup co-hosted by Gabon and Equatorial Guinea. }\end{array}$ \\
\hline Libya & 1992, 1993, 1999 & $\begin{array}{l}\text { 1989: Libya, Algeria, Morocco, Mauritania and Tunisia joined together to form the Arab } \\
\text { Maghreb Union. } \\
\text { 2003: Libya was elected chairman of the UN Human Rights Commission despite opposition. }\end{array}$ \\
\hline Mauritius & 1998, 2009 & $\begin{array}{l}\text { 2002: Both the president and vice-president resigned after refusing to sign a controversial } \\
\text { anti-terrorism bill. } \\
\text { 2012: The president Anerood Jugnauth has been in open conflict with the prime minister } \\
\text { Navinchandra Ramgoolam, said he was resigning to join the opposition. }\end{array}$ \\
\hline South Africa & 1992,1998 & $\begin{array}{l}\text { 1993: The US president Clinton signed legislation lifting remaining US sanctions against } \\
\text { South Africa, and announced an initiative to spur investment in South Africa's black private } \\
\text { sector. } \\
\text { 1998: The US president Clinton visited South Africa, stood with president Nelson Mandela in } \\
\text { a racially integrated South African parliament to salute a country that was "truly free and } \\
\text { democratic at last". }\end{array}$ \\
\hline
\end{tabular}

Notes: The break dates reported in this table are based on the significant breaks identified by the RALS-LM unit root tests. 